IZA DP No. 9462

Demanding Occupations and the Retirement Age

Niels Vermeer

Mauro Mastrogiacomo

Arthur van Soest

October 2015 


\title{
Demanding Occupations and the Retirement Age
}

\author{
Niels Vermeer \\ Dutch Ministry of Finance and Netspar
}

Mauro Mastrogiacomo

De Nederlandsche Bank, VU University Amsterdam and Netspar

Arthur van Soest

Tilburg University, Netspar and IZA

\author{
Discussion Paper No. 9462 \\ October 2015
}

\author{
IZA \\ P.O. Box 7240 \\ 53072 Bonn \\ Germany \\ Phone: +49-228-3894-0 \\ Fax: +49-228-3894-180 \\ E-mail: iza@iza.org
}

Any opinions expressed here are those of the author(s) and not those of IZA. Research published in this series may include views on policy, but the institute itself takes no institutional policy positions. The IZA research network is committed to the IZA Guiding Principles of Research Integrity.

The Institute for the Study of Labor (IZA) in Bonn is a local and virtual international research center and a place of communication between science, politics and business. IZA is an independent nonprofit organization supported by Deutsche Post Foundation. The center is associated with the University of Bonn and offers a stimulating research environment through its international network, workshops and conferences, data service, project support, research visits and doctoral program. IZA engages in (i) original and internationally competitive research in all fields of labor economics, (ii) development of policy concepts, and (iii) dissemination of research results and concepts to the interested public.

IZA Discussion Papers often represent preliminary work and are circulated to encourage discussion. Citation of such a paper should account for its provisional character. A revised version may be available directly from the author. 


\section{ABSTRACT}

\section{Demanding Occupations and the Retirement Age $^{1}$}

In several countries where pensions are reformed and the retirement age is increased, the issue came up to make an exception for workers with demanding occupations, since health considerations may make it unreasonable to expect them to work longer. We analyze unique Dutch survey data on the public's opinions on what are demanding occupations, on whether it is justified that someone with a demanding occupation can retire earlier, and on the willingness to contribute to an earlier retirement scheme for such occupations through higher taxes. A representative sample of Dutch adults answered several questions about hypothetical persons with five different jobs. We use panel data models, accounting for confounding factors affecting the evaluations of the demanding nature of the jobs as well as their reasonable retirement age or willingness to contribute to an early retirement scheme. We find that the Dutch think that workers in demanding occupations should be able to retire earlier. A one standard deviation increase in the perceived demanding nature of an occupation translates into a twelve months decrease in the reasonable retirement age and a 30 to 40 percentage points increase in the willingness to contribute to an early retirement scheme for that occupation. There is some evidence that respondents whose own job is similar to the occupation they evaluate find this occupation more demanding than other respondents, but respondents are also willing to contribute to early retirement of demanding occupations not similar to their own.

JEL Classification: J26, J81, H55

Keywords: retirement age, public pensions, job characteristics, social preferences

Corresponding author:

Arthur van Soest

Tilburg School of Economics and Management

Econometrics and Operations Research

Tilburg University

P.O. Box 90153

5000 LE Tilburg

The Netherlands

E-mail: a.h.o.vansoest@tilburguniversity.edu

\footnotetext{
${ }^{1}$ The authors thank Rob Alessie, Harry van Dalen, Rob Euwals, Johannes Hers, Lieke van der Horst, Giovanni Mastrobuoni, Jan van Ours, Adriaan Soetevent, Daniel van Vuuren, and participants of the Netspar Pension Day 2013, the Labor and Health Seminar at Tilburg University, the seminar at VU University, the Health seminar at the Erasmus University Rotterdam, the Dutch Central Bank and the Netspar International Pension Workshop 2014 for valuable comments. Additionally, the authors thank Maarten van Rooij and Daniel van Vuuren for fruitful discussions in constructing this survey and CentERdata for excellent support in implementing the survey. This paper uses data of the DNB Household Survey. The authors thank Netspar for research funding. This paper reflects the opinions of the authors and does not necessarily reflect the opinion of the Dutch Ministry of Finance or DNB.
} 


\section{Introduction}

Many governments are reforming pension schemes to tackle concerns about their fiscal sustainability, due to ageing of the population. A widely employed and highly visible reform is to increase the statutory retirement age (OECD, 2011) - the age at which individuals are entitled to 'full' retirement benefits in the first pillar of public pensions. This seems reasonable in most cases, since not only life expectancy has risen and is still increasing, but also "healthy life expectancy", that is, the number of years spent without any serious disability (Majer et al., 2013). In other words, the trend is that health at a given age tends to increase, so that in most occupations, workers will be able to work and remain productive longer. These facts taken together naturally lead to the generic policy of increasing the statutory retirement age, to guarantee the sustainability of a (usually payas-you-go) first pillar pension, with future cohorts paying premiums longer and claiming benefits for a shorter time period.

Concerns, however, arose about the consequences of such a generic policy for workers in demanding occupations, who currently already often stop working before the statutory retirement age, entering early retirement, unemployment, or disability benefits. The policy debate in the Netherlands has, for example, emphasized that low-skilled workers in the construction sector cannot be expected to work longer since their job requires a level of physical health that they often can no longer maintain at an older age, partly because the heavy work they have done during their whole career has deteriorated their health. The government suggested making an exception for this kind of physically demanding occupations. ${ }^{2}$ Many also disagreed with this idea however, and pointed to the large costs of such policies in other countries (cf. Boldrin et al. 2004). They suggested that occupations should become less demanding by investing in technological improvements. If workers in demanding occupations could get access to early retirement, such investments could become unattractive ( OECD, 2007).

In the debate that followed, several other occupational groups have also argued for exceptions, not only based upon physical demands but also because of the mentally

\footnotetext{
${ }^{2}$ See, e.g., http://www.nu.nl/economie/2152950/kabinet-blijft-bij-lijst-zware-beroepen.html
} 
demanding nature of their occupation. This is in line with Borghans and ter Weel (2012) who argue that putting up a (subjective) list of heavy occupations will not work in practice, since too many groups will claim they have to be included. On the other hand, it is also not easy to define objectively what constitutes a demanding occupation. Because of these practical considerations, the Dutch government in the end decided to raise the statutory retirement age without making any exceptions. Starting in 2013 the statutory retirement age is increasing and will increase further in the near future. The issue of differentiating among occupations may therefore come back on the policy agenda. Moreover, a very similar debate now seems to have started in Belgium, ${ }^{3}$ and in the UK, the new Labour leader Jeremy Corbyn stated, "Manual workers in 'physically demanding jobs' should be allowed to retire early." 4 This illustrates that the issue is relevant in many countries where pension systems are reformed and the standard retirement age increases.

This study analyzes the opinion of the Dutch on early retirement arrangements of demanding occupations, where data on the people's views were collected at the time when the policy debate on demanding occupations was taking place. This is important since the shape and implementation of social security reforms in general and pension reforms in particular often depends on the opinion of the general public (Cremer and Pestieau, 2000; O'Donnell and Tinios, 2003). For the political feasibility of differentiation in the statutory retirement age, the public's willingness to accept such an arrangement and its views on what it should look like may therefore play a crucial role. We study whether the Dutch population is willing to contribute to early retirement schemes for specific occupations. We investigate which characteristics make an occupation demanding in the public's view, and how the perceived burden of an occupation affects the reasonable retirement age and the willingness to contribute to an occupation-specific early retirement scheme. Moreover, we analyze whether people are only willing to contribute to a scheme for occupations similar to their own (possibly reflecting self-interest) or also to schemes

\footnotetext{
${ }^{3}$ E.g., http://pvda.be/artikels/regering-wil-debat-met-sociale-partners-over-zware-beroepen-maar-niet-echt ${ }^{4}$ http://www.telegraph.co.uk/news/politics/Jeremy_Corbyn/11837898/Jeremy-Corbyn-Manual-workers-inphysically-demanding-jobs-should-be-allowed-to-retire-early.html
} 
for other occupations, where they cannot expect direct gains for themselves. The latter would reflect some kind of social preferences (see, e.g., DellaVigna, 2009). ${ }^{5}$

The survey questions used in this study refer to pensions in general and not specifically the first pillar. In the Dutch system, the first pillar pensions of workers with demanding occupations are particularly relevant, because (physically) demanding occupations are often low-paid, and first pillar pensions play a much larger role for low income than for higher income groups. This is because the first pillar provides an essentially flat basic income, which is the main source of income for those with low lifetime earnings, but only a limited part of total pension income for higher lifetime earnings groups who have built up a second pillar occupational pension (mandatory for almost all employees). This implies that the effects of an increase in the statutory retirement age are heterogeneous, reducing total retirement wealth by a much larger fraction for low income than for high-income individuals. It also means that "repairing" the increase in the eligibility age for state pensions for low-income earners through an earlier occupational pension is relatively expensive - this pension has to be much higher in the years before the state pension can be claimed.

Several earlier studies have also proposed to differentiate the statutory retirement age. Life expectancy increases with income. ${ }^{6}$ Bovenberg et al. (2006) therefore argue that the statutory retirement age should not be uniform but linked to the (remaining) life expectancy of the socio-economic group. Ravesteijn et al. (2013) analyze the relation between occupation and health, and conclude that workers whose poor health was caused by occupational characteristics should be exempted from an increase in the statutory retirement age if their occupational health damage was not compensated through a wage premium.

The link between disability insurance and early retirement makes the issue even more relevant. Older workers with severe health issues may be eligible for disability

\footnotetext{
${ }^{5}$ Of course, the arrangement could be in the interest of a family member or friend who has such an occupation.

${ }^{6}$ For instance, Kalwij et al. (2013) find that low-income individuals have an approximately 2.5 years shorter remaining life expectancy at 65 years of age than high-income individuals.
} 
insurance benefits. Since the 1990's, policy reforms were implemented making entry into the Dutch disability insurance program more difficult, and inflow rates into disability insurance have substantially decreased as a consequence (García-Gómez et al., 2011). With stricter access to disability insurance, early retirement has become more relevant, particularly for older individuals with demanding occupations for whom work limiting health problems are more prevalent.

Our findings lead to clear conclusions on what the public considers a demanding occupation. Respondents attach a large weight to physical effort while mental effort or job stress is not important. The see "Construction worker" as a burdensome occupation, while "teacher" and "desk job" are not. This also implies a lower reasonable retirement age and a higher willingness to contribute to an early retirement scheme for construction workers than to a scheme for other occupations. The data show that people are willing to contribute to early retirement schemes of construction workers even if this occupation is not similar to their own. For other occupations, such as desk jobs or teacher, this is much less the case. This suggests that self-interest is not the only thing driving the support for early retirement of demanding occupations - at least part of it is due to other factors such as social preferences.

The remainder of this paper is organized as follows. Section 2 discusses some background literature and section 3 describes the relevant institutional framework in the Netherlands. Section 4 describes the survey design and the data. Section 5 introduces the econometric model and discusses the empirical results. Section 6 concludes.

\section{Related literature}

There is a vast literature on the economic and non-economic determinants of retirement. Gruber and Wise (1999, 2004), among many others, analyzed the interplay between retirement benefits and exit rates from the labor market in various countries. More relevant for the current study is the role of health. Individuals could find themselves unable to continue working due to health problems. Indeed, structural models of retirement behavior often control for health status. See, for instance, Gustman and Steinmeier (2005) or Rust and Phelan (1997). Grossman (1972) argues that health takes the form of a 
capital stock that depreciates over time. To keep the health stock at a certain level, investments are needed. In the Grossman model, the higher educated are expected to invest more in health since they can produce health more efficiently. The model implies that the determinants of health are income and education (along with the efficiency of the health care technology).

Case and Deaton (2005) add a link between occupation and health. If workers can generate earnings from their health capital or human capital, lower-educated workers may find it optimal to let their health stock depreciate more quickly as they do not have access to a large stock of human capital. Examples could be stressful or physically demanding occupations. Empirically, they find that health depreciates faster over the life cycle for individuals in manual occupations. Sindelar et al. (2007) find a link between first occupation and health at later ages, attempting to alleviate concerns about causality. Fletcher et al. (2011) find a detrimental impact of physically demanding job conditions on health, particularly for females and older workers. The theory of compensating wage differentials predicts that workers in physically demanding jobs would get a higher wage to compensate for this health loss, but the empirical literature does not find convincing evidence for this. In additional estimations Fletcher et al. (2011) add the cumulative number of hours worked and cumulative labor income and find that adding these reduces the effect of physical demands on health.

In other studies on compensating wage differentials, the evidence is mixed. In a study with Finnish data, Böckerman and Ilmakunnas (2006) find that a job disamenity has a negative effect on job satisfaction but much less on individual wages. On the other hand, Böckerman et al. (2011) find that higher job insecurity is associated with a higher individual wage in Finland, while it has no effect on job satisfaction. They conclude that the higher wage compensates for this job disamenity. Bryson et al. (2012) find that wages in Britain are positively correlated with job anxiety but also with non-pecuniary job satisfaction. This is inconsistent with an explanation of compensating wage differentials, which would imply that job characteristics leading to lower non-pecuniary job satisfaction should be compensated by a higher wage. 
The possible absence of compensating wage differentials for demanding occupations, for instance due to the impossibility to assess future health costs of current choices, creates scope for policy intervention. Creating an opportunity for earlier retirement seems a particularly effective way of compensating individuals for their demanding occupations since people in demanding occupations may find it difficult to continue working when they get older due to health issues. Neumark and Song (2012) indeed find that physical challenges in the job form a barrier to extending work lives. Holden (1988) finds that for men in the US, working in a physically demanding job is associated with lower chances of working after retirement (that is, when receiving retirement benefits), but she finds no such association for women. Filer and Petri (1988), also using US data, find that physical demands and stress both lead to earlier retirement; workers with physically demanding jobs also prepare for this by accumulating higher pensions. Using Danish data from administrative records, Datta Gupta et al. (2012) find that workers with physically demanding jobs more often face a temporary work incapacity, but they find no significant relation with permanent work incapacity. Van Solinge and Henkens (2008) find that Dutch retirees who held physically demanding jobs are more satisfied with their retirement, providing indirect evidence for the negative effects of physical job demands at older ages. De Grip et al. (2013) find that older cohorts of Dutch employees in the public sector expect to retire earlier if they have a physically demanding job.

An important segment of the literature focuses on the public's opinion about pension policies and analyzes the attitudes toward reforming pensions, specifically considering changes in the retirement age. Boeri et al. (2002) survey the opinion of European citizens on reforms aimed at maintaining the sustainability of state pensions. They find high opposition against reforms and suggest that this is at least to some extent due to selfishness. Van Groezen et al. (2009) show that European citizens, also because of the allowed retirement age, more often report a preference for a public pension system, rather than a private. Jaime-Castillo (2013) finds that participants in pension schemes with more solidarity are more willing to contribute to the system.

Joulain and Mullet (2001) analyze French survey data on what people consider the "appropriate" retirement age for a large number of occupations, with varying physical 
and mental demands. Their questions do not refer to pension reforms or other retirement policies. They find a lower "appropriate" retirement age for occupations perceived as physically demanding, while no effect was found of cognitive or social and organizational demands of the occupation. They argue that this is in line with the fact that older workers are perceived as cognitively able and socially responsible until long after the usual retirement age.

Why would individuals be willing to contribute to early retirement schemes for demanding occupations? As stated in the introduction, this can have two reasons: selfidentification with these occupations or social preferences not driven by self-interest. These social preferences can take various guises, like altruism, inequality aversion or reciprocity. Fehr and Schmidt (2006) define altruism as kindness unconditional on payoffs received by others. This means that individuals will care for the payoff of others regardless of the final distribution of outcomes. ${ }^{7}$ On the other hand, inequality averse individuals take the distribution of outcomes into account and prefer a higher payoff for another individual only if this reduces inequality. Charness and Rabin (2002) show with lab experiments that individuals are willing to sacrifice own resources to increase the pay-offs of other participants, especially the least well-off participants. Tyran and Sausgruber (2006) find that a model with agents who are inequality averse better predicts the voting outcomes in a redistribution experiment than a model with rational and self-interested agents. Fehr and Gächter (2000) define reciprocity as conditional kindness: people behave more cooperatively in response to nice and friendly behavior of others. Unfriendly actions, however, meet uncooperative or even hostile responses. Fong et al. (2005) find support for policies that rely on reciprocity. For instance, individuals are willing to give financial support to people struck by bad luck but not to people who are poor because they are unwilling to work.

\footnotetext{
${ }^{7}$ Altruism is a broad notion. It can also contain 'impure' altruism: the warm-glow effect (Andreoni, 2006). For instance, individuals may donate money to charity because it makes them feel better about themselves. Put this way giving to charity can be considered as selfish.
} 


\section{Dutch retirement institutions}

The pension and retirement system in the Netherlands is relevant as it provides the context in which the survey questions were answered. Pensions are organized in three pillars. The first pillar is the pay-as-you-go state pension. Every resident of the Netherlands is entitled to these benefits from the statutory retirement age. Since 2009, a public policy debate revolved around an increase in this age. In spring 2012, the government decided to increase this age in steps, from 65 years of age in 2013 to 67 years of age in 2021. After that, the statutory age will be linked to life expectancy. The benefit level depends on the number of years one has lived in the Netherlands and is independent of (lifetime) income. The state pension provides a basic income for the elderly that is usually enough to keep them out of poverty and explains why poverty among the elderly is low (except for specific groups such as immigrants or people with large debts; see Ministry of Social Affairs and Employment, 2013).

Company or sector-level retirement schemes represent the second pillar. Participation in these schemes is generally mandatory for employees. Employment in a particular sector or company implies automatic enrollment in the relevant pension plan. These schemes can be either Defined Contribution (DC) or Defined Benefit (DB). The benefit level is mainly determined by the wage and by how long the employee has contributed. Earlier or later take-up of pensions is often possible so that the claiming age can differ from the statutory retirement age.

Finally, voluntary contributions are possible in the third pillar. These additional private retirement savings are tax-deductible under certain conditions (implying that income used for these savings is not taxed during the accumulation phase, while the benefits are taxed in the payout phase).

The pay-as-you-go nature of the national level first pillar implies that individuals with various backgrounds and occupations contribute to each other's retirement schemes. On the other hand, the second pillar is capital-funded and organized at the company or sector level. 


\section{Data and study design}

We have fielded a one-time survey on demanding occupations (DO) in the CentERpanel. This panel is based upon a representative sample of the Dutch adult population who are interviewed weekly over the Internet on a large variety of topics. People without access to Internet get the necessary equipment to participate so that also the non-Internet part of the population is covered. The fact that there are no personal interviews minimizes the risk that the answers suffer from social desirability bias. The CentERpanel also incorporates the annual DNB Household Survey (DHS), in which respondents answer questions related to different aspects of their financial situation, like income and wealth. This readily provides us with many background characteristics of the respondents. 2,840 household members above the age of 15 were asked to participate in the DO survey and 1,845 of them took part, giving a participation rate of $65 \%$. Data collection took place in the week of May 11 through May 16 2012, at a time when an increase of the statutory retirement age was under consideration (see Section 3). The descriptive statistics we present are weighted by age, gender, education and individual annual income to correct for unit non-response and obtain a representative view of the Dutch population.

In the DO survey, respondents were asked what they thought about the demanding nature of specific occupations and about reasonable retirement ages for these occupations. They were also asked whether they would be willing to contribute to an early retirement scheme for such occupations. Respondents were first given an introduction into five fictive vignette persons with various occupations, emphasizing that these persons all had the same income and age and the same work experience - The only difference was their occupation. The five specific occupations were construction worker, teacher, nurse, person with a desk job, and fireman. All respondents answered questions about all these five occupations. Appendix A shows the exact wording of the questions. The order of the questions and the gender of the vignette persons were randomized over the respondents, with the exception of construction worker and fireman. For these two occupations, all respondents got male names. An example of the first type of questions, on the reasonable retirement age, is the following: 
John has worked for 30 years at a desk job. What do you think is a reasonable retirement age for John?

Respondents could answer 'younger than 60 ', '60', '61', ..., '70', or 'older than 70 '.

The other questions of this type replace "desk job" by another occupation. Figure 1 presents the sample distribution of the answers.

Figure 1 Reasonable retirement ages

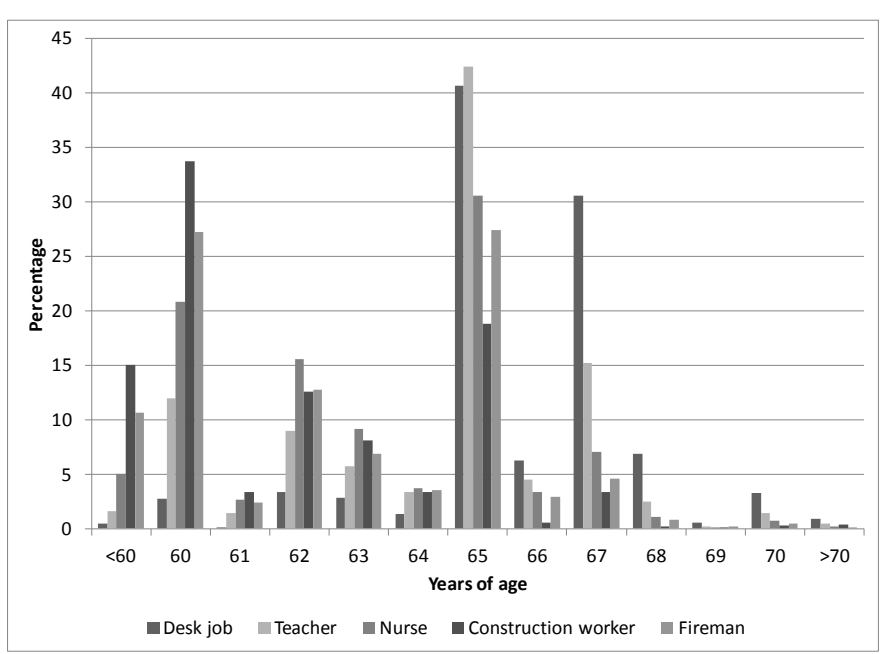

Explanation: distribution of answers to the question: 'What do you think is a reasonable retirement age for ... (fictive name with listed occupation)?' $N=1,840$. Source: DO, own computations

The large differences across occupations seem plausible and raise confidence that respondents understood the questions. The answers indicate that according to most respondents, early retirement is reasonable for construction workers, whereas people with desk jobs should retire later. The mean reasonable retirement age for the occupations ranges from almost 62 for the construction worker to almost 66 years for the individual with a desk job. ${ }^{8}$

After answering some other questions (not considered in this study), the respondents indicated whether they were willing to contribute, by paying higher income taxes, to early retirement schemes for each of the five fictive persons. Respondents

\footnotetext{
${ }^{8}$ For the occupations of teacher, nurse and fireman the means of the reported reasonable retirement ages were $64.3,63$ and 62.5 years of age, respectively.
} 
answered on a five point scale ranging from 'certainly not' to 'certainly yes'. Figure 2 shows the distribution of the answers.

Figure 2 Willingness to contribute to early retirement schemes

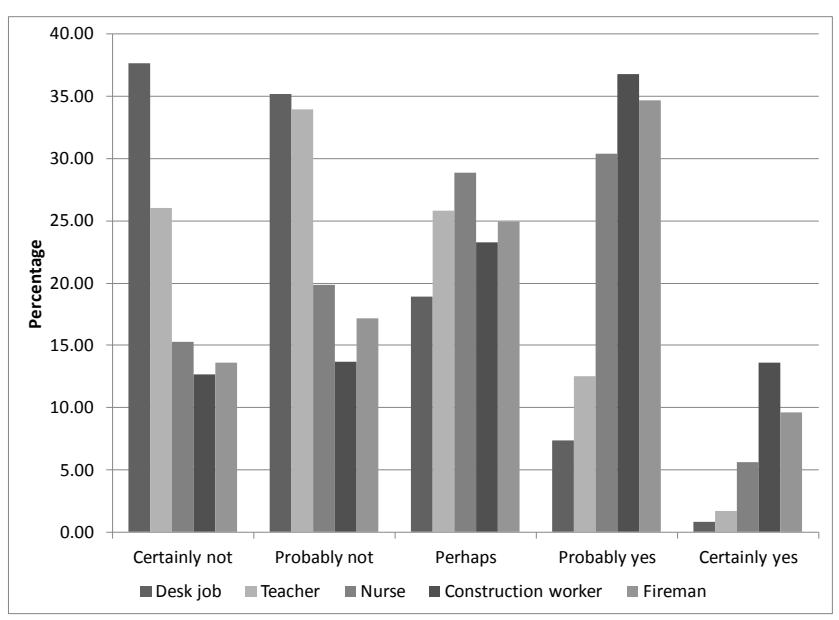

Explanation: Answers to the question: 'Are you willing to contribute as a tax payer to an early retirement scheme for ... (fictive name with listed occupation) ?' $N=1,835$. Source: DO, own computations

Approximately $50 \%$ of the respondents indicate they are certainly or probably willing to contribute to an early retirement scheme for construction workers, much more than for any of the other four occupations. It is possible that respondents show high willingness to pay, because they expect to be able to benefit themselves of such a scheme. On the other hand, as we will discuss below, the data also show that only $9 \%$ of the respondents consider their own occupation similar to that of 'construction worker', suggesting that many respondents are willing to contribute even if they do not expect to benefit directly.

The last vignette-related question asked how demanding respondents considered the occupations of the five fictive persons. For example:

'Do you think that the occupation of John (has a desk job) is demanding?'

Respondents answered on a five-point scale ranging from 'undemanding' to 'demanding'.

Figure 3 shows that respondents think that construction workers have the most demanding of the five occupations, followed by nurses and firemen. The occupations of teachers and especially desk jobs are considered much less demanding. 
Figure 3 How demanding is each occupation?

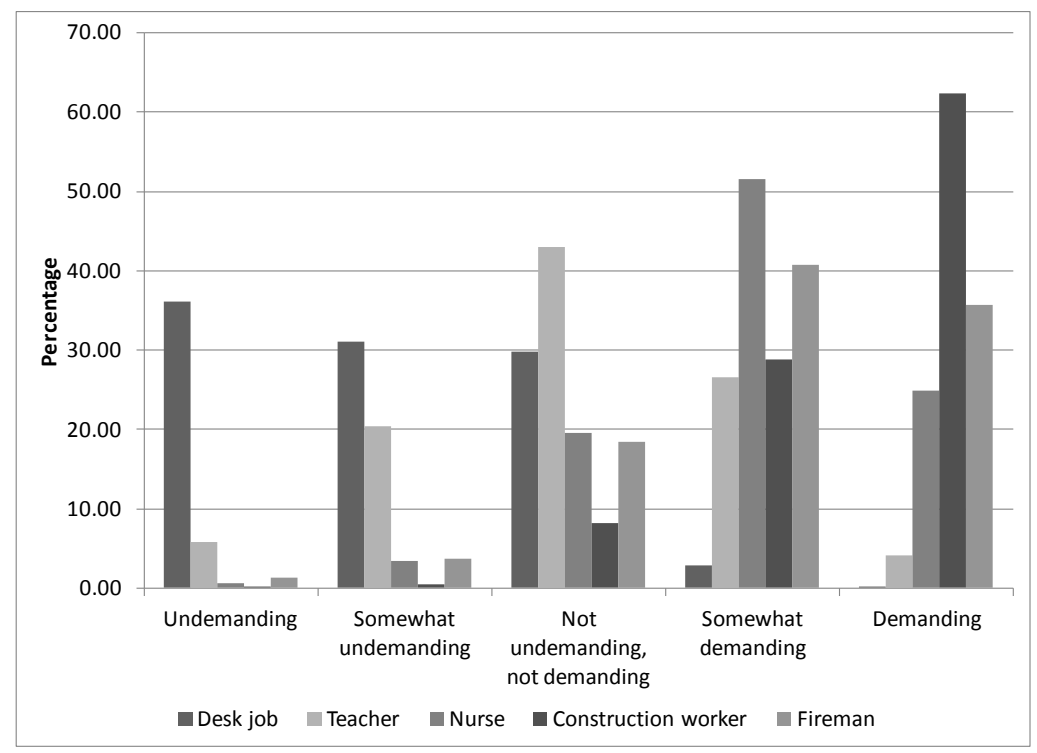

Explanation: answer to the question: "Do you think that the occupation of ... (fictive name with listed occupation) is demanding?" $N=1,835$. Source: DO, own computations

The next questions asked to what extent certain job properties make an occupation demanding. The properties range from physically demanding work to working under time pressure. Figure 4 shows that occupations are primarily considered demanding due to the physical workload, followed by working in shifts and working long hours or in an irregular manner.

Figure 4 What makes an occupation demanding?

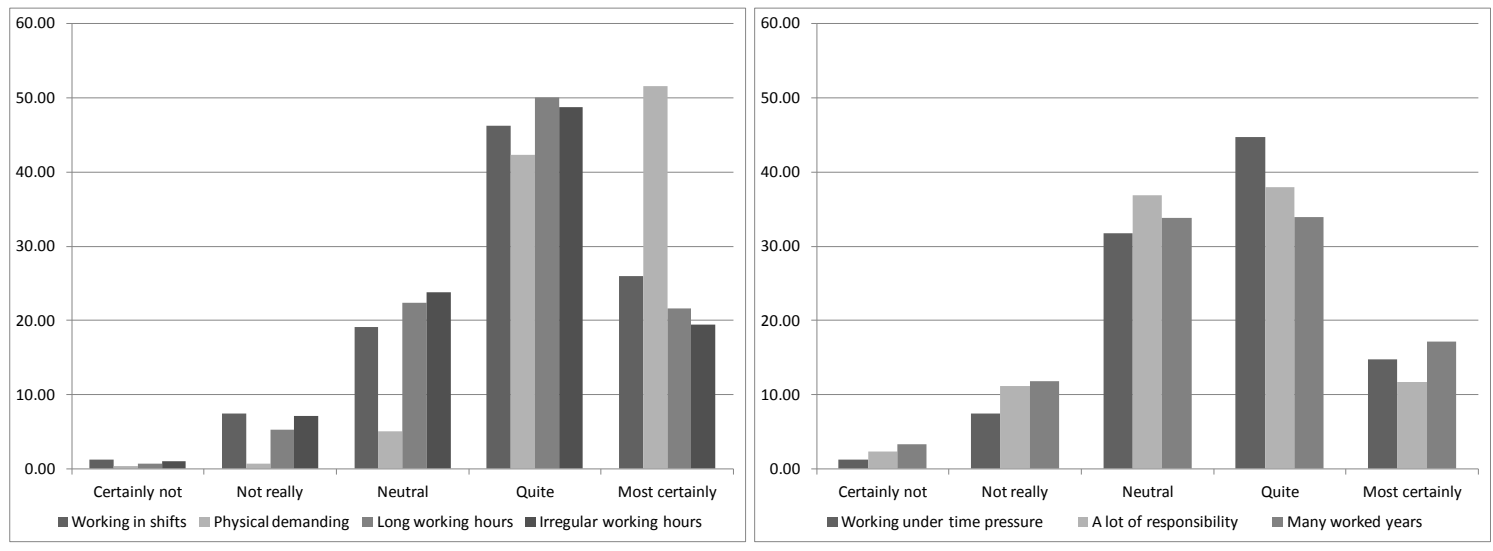

Explanation: answer to the question: "What attribute makes an occupation demanding in your view?" $N=1,834$. Source: DO, own computations 
Finally, the respondents were asked which occupation resembles their own occupation most closely. They had to choose one of the five occupations. Figure 5 shows that the majority of the respondents identify themselves with working in a desk job.

Figure 5 With which of the five occupations do respondents identify?

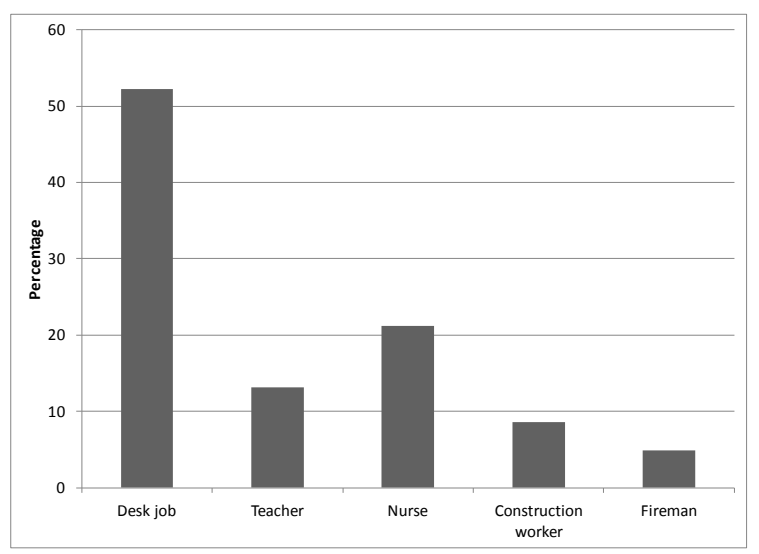

Explanation: answer to the question: "Which of the five occupations is most similar to your own occupation?" $N=1,787$. Source: DO, own computations.

Note that the survey questions are hypothetical and not incentivized. When, for example, respondents say they would be willing to contribute to an early retirement scheme of a certain occupation, we cannot guarantee that they would actually contribute to such a scheme if given the actual choice. The questions also do not provide information on how much they should contribute, so the answers do not reflect an actual trade off but an attitude towards special arrangements for some occupations and not for others. This suggests that more value should be attached to the qualitative differences across the five occupations than to the absolute levels of the willingness to contribute, etc.

The descriptive statistics above suggest that most respondents find it reasonable that workers with physically demanding occupations retire earlier than others retire, and are willing to contribute to this by paying more taxes. The relationship between physical burden, demanding occupations and reasonable retirement ages is in line with Joulain and Mullet (2001) who found that "appropriate" retirement ages are lower for occupations perceived as more physically demanding (cf. Section 2). In the next section, we will use econometric models to analyze the factors that drive the reported reasonable retirement age and willingness to contribute. 


\section{Model and results}

\subsection{Demanding occupations and reasonable retirement age}

We use the following model to analyze the relationship between the extent to which certain occupations are perceived to be demanding and the associated reasonable retirement ages. Respondents evaluate how demanding the five occupations are according to equation 1:

$$
y_{i j}^{*}=X_{i}^{\prime} \delta_{j}+Z_{i} \alpha_{j}+W_{i}^{\prime} \lambda_{j}+\vartheta_{i}+u_{i j}
$$

The latent dependent variable $y_{i j}^{*}$ increases in the extent that respondent $i(i=1, \ldots, N)$ thinks occupation $j(j=1, \ldots, 5)$ is demanding. This depends on respondent characteristics $\left(X_{i}\right)$, on which of the five jobs the respondent identifies with $\left(Z_{i}\right)$, and on which characteristics make a job demanding in the view of the respondent $\left(W_{i}\right)$. Unobserved heterogeneity across respondents is captured by $\vartheta_{i}$; for a given respondent, this is the same for all occupations and represents the respondent's tendency to see any occupation as demanding. Finally, an idiosyncratic error term is included, assumed to be drawn from a standard normal distribution $\left(u_{i j} \sim N(0,1)\right)$, independent of the other terms on the right hand side of equation 1 and independent across occupations.

The latent dependent variable is not observed. Instead, a respondent answers in five distinct categories, from 'undemanding' (1) to 'demanding' ( 5$)$. This is captured using an ordered response equation:

$$
\begin{aligned}
& Y_{i j}=k \text { if } c_{k-1}<y_{i j}^{*} \leq c_{k} \\
& \text { with } 1 \leq k \leq 5, c_{0}=-\infty \text { and } c_{5}=\infty
\end{aligned}
$$

The equation for the reasonable retirement ages for the five occupations is given by:

$$
R_{i j}=\gamma_{j} y_{i j}^{*}+X_{i}^{\prime} \eta_{j}+Z_{i} \beta_{j}+\rho_{i}+\varepsilon_{i j}
$$

The reasonable retirement age $R_{i j}$ for respondent $i$ and occupation $j$ depends on the same variables as in equation 1, except that it does not include the variables $W_{i}$ referring to the respondent's view on which job characteristics make an occupation demanding. These variables are assumed to affect the reasonable retirement age only through their effect on how demanding an occupation is considered $\left(y_{i j}^{*}\right)$. It seems better to include $y^{*}$ than dummies for the observed categorical outcome $Y$, since $Y$ depends on the scale that happens to be used in the survey. Unobserved respondent specific heterogeneity is denoted 
by $\rho_{i}$. The idiosyncratic errors $\varepsilon_{i j}$ are assumed to be drawn from $N\left(0, \sigma_{\varepsilon}^{2}\right)$, independent of each other and of the other terms on the right hand side of equations 1 and 3 .

Combining equations 1 and 3 leads to:

$$
R_{i j}=W_{i j}{ }^{\prime} \gamma_{j} \lambda_{j}+X_{i}^{\prime}\left(\gamma_{j} \delta_{j}+\eta_{j}\right)+Z_{i}\left(\beta_{j}+\alpha_{j} \gamma_{j}\right)+\rho_{i}+\gamma_{j} \vartheta_{i}+\varepsilon_{i j}+\gamma_{j} u_{i j}
$$

Equation 4 shows that with the identifying assumption that job characteristics do not influence the reasonable retirement age directly, $y$ can be identified. The unobserved heterogeneity terms in equations 1 and 3 are assumed to be drawn from a bivariate normal distribution, independent of the error terms and all explanatory variables in eq. 4:

$$
\left(\begin{array}{l}
\vartheta_{i} \\
\rho_{i}
\end{array}\right)=N\left(\left(\begin{array}{l}
0 \\
0
\end{array}\right),\left(\begin{array}{cc}
\sigma_{\vartheta}^{2} & \tau \sigma_{\rho} \sigma_{\vartheta} \\
\tau \sigma_{\rho} \sigma_{\vartheta} & \sigma_{\rho}^{2}
\end{array}\right)\right) .
$$

This implies that the unobservable parts of equations 1 and 3 are correlated if $\tau$ is not equal to zero. The parameters of the model are estimated simultaneously using maximum simulated likelihood with 100 Halton draws. ${ }^{9}$ Appendix B presents details of the ( simulated) likelihood. The independence assumptions on the error terms imply that the conditional likelihood given the unobserved heterogeneity terms can be written as the product of five contributions for the five occupations, each of which as the product of a density (for $R_{i j}$, using eq. 4) and a conditional probability (for $Y_{i j}$ given $R_{i j}$, using eq. 1). The unconditional likelihood is the expected value of the conditional likelihood over the unobserved heterogeneity terms and it can be approximated using a simulated mean. ${ }^{10}$

Table 1 presents the estimates of equation $1 .{ }^{11}$ The respondents tend to focus on physical demands: predictions based upon the estimates in Table 1 show that construction workers have the most demanding occupation, followed by firemen, nurses, teachers, and individuals with a desk job, ${ }^{12}$ in line with Figure 3 . The coefficients on "Physical" confirm the importance of physical burden: respondents thinking that a physical burden certainly makes a job demanding evaluate construction worker as more demanding job and a desk

\footnotetext{
${ }^{9}$ For Halton draws the STATA program mdraws is used (see Cappellari and Jenkins, 2006). Using a larger number of draws does not change the results.

${ }^{10}$ An alternative would be to first estimate equation 1 and the reduced form of equation 4 separately, and then perform minimum distance to estimate the structural parameters in a second step by minimum distance. An advantage of the (simulated) ML approach is that it also gives the estimated covariance matrix of the unobservables.

${ }^{11}$ Appendix D presents the descriptive statistics of the background variables for the estimation sample.

12 The calculation involves computation of the mean of the predicted values for the latent variable of equation (1). Fireman and nurse are close to each other for the second place in this ranking.
} 
job as less demanding than other respondents. Other attributes also play a role, like working in shifts, many years worked, and irregular working hours in the case of nurses. Respondents convinced that a lot of responsibility makes a job demanding, tend to evaluate a desk job as more demanding than other respondents.

The bottom part of Table 1 shows that, keeping perceived job characteristics constant, self-identification matters. Respondents who identify their own job with a desk job, teacher, or fireman consider this job as more demanding than other respondents. On the other hand, all respondents, regardless of their own job, think that construction worker is a demanding occupation. Interestingly, teachers consider the job of a nurse as more demanding than nurses themselves do. Teachers, nurses, construction workers and firemen consider desk jobs as less demanding than those with a desk job do. Gender of the vignette person also matters: for the three occupations where we used male or female names, the jobs of female fictive persons were evaluated as more demanding.

Table 2 shows the estimation results for the reasonable retirement age (equation 3 ). The significantly negative estimates of the $y$-coefficients show that respondents think that workers with demanding jobs should be able to retire earlier than others. To illustrate the magnitude of the effect: on average, an increase of one standard deviation in how demanding an occupation is $\left(y^{*}\right)$ would reduce the reasonable retirement with one year. The magnitude of the effect can also be computed comparing two benchmark respondents who think a particular occupation is demanding and undemanding. Both are higher educated males with a net household income larger than 2600 Euros (also see appendix E). The resulting difference between the reasonable retirement ages given by these two respondents amounts to almost three years earlier retirement in the case of fireman and 1.6 years for people with desk jobs. ${ }^{13}$ This is the same order of magnitude as the increase in the statutory retirement age in the Netherlands (see section 3 ).

\footnotetext{
13 The baseline respondent who thinks that an occupation is somewhat undemanding is defined at the average of the first two thresholds $(=0.39$; see Appendix D). The baseline respondent who thinks that an occupation is somewhat demanding is defined at the average of the last two thresholds $(=3.21)$. The difference $(=2.824)$ is multiplied with the various $y$ 's to get the estimated effect on the reasonable retirement age. For fireman the effect is largest: 2.7 years earlier retirement; for desk jobs it is the smallest: 1.6 years earlier retirement.
} 
Table 1 Key estimation results for evaluation how demanding occupations are (equation 1)

\begin{tabular}{|c|c|c|c|c|c|}
\hline & & Evaluation & how demanding & occupations are & \\
\hline & (1) & $(2)$ & (3) & (4) & (5) \\
\hline & Desk job & Teacher & Nurse & Construction & Fireman \\
\hline & & & & Worker & \\
\hline \multirow[t]{2}{*}{ Shifts: Quite } & $0.167 * *$ & 0.119 & $0.192 * *$ & 0.025 & $0.235 * * *$ \\
\hline & $(0.079)$ & $(0.077)$ & $(0.078)$ & $(0.087)$ & $(0.078)$ \\
\hline \multirow[t]{2}{*}{ Shifts: Certainly yes } & 0.051 & $0.164 *$ & $0.373 * * *$ & 0.042 & $0.326 * * *$ \\
\hline & $(0.100)$ & $(0.096)$ & $(0.099)$ & $(0.113)$ & $(0.099)$ \\
\hline \multirow[t]{2}{*}{ Physical: Quite } & $-0.662 * * *$ & -0.194 & 0.196 & $0.986 * * *$ & $0.602 * * *$ \\
\hline & $(0.133)$ & $(0.130)$ & $(0.131)$ & $(0.134)$ & $(0.131)$ \\
\hline \multirow[t]{2}{*}{ Physical: Certainly yes } & $-0.927 * * *$ & -0.189 & $0.504 * * *$ & $2.195 * * *$ & $1.067 * * *$ \\
\hline & $(0.136)$ & $(0.132)$ & $(0.134)$ & $(0.143)$ & $(0.134)$ \\
\hline \multirow[t]{2}{*}{ Time Pressure: Quite } & $0.383 * * *$ & $0.268 * * *$ & -0.001 & $-0.217 * * *$ & $-0.185 * *$ \\
\hline & $(0.075)$ & $(0.072)$ & $(0.074)$ & $(0.084)$ & $(0.074)$ \\
\hline \multirow[t]{2}{*}{ Time Pressure: Certainly yes } & $0.475 * * *$ & $0.486 * * *$ & $0.275 * *$ & $-0.335 * *$ & $-0.300 * *$ \\
\hline & $(0.117)$ & $(0.113)$ & $(0.118)$ & $(0.135)$ & $(0.117)$ \\
\hline \multirow[t]{2}{*}{ Responsibility: Quite } & $0.285 * * *$ & $0.277 * * *$ & $0.247 * * *$ & 0.027 & 0.106 \\
\hline & $(0.074)$ & $(0.071)$ & $(0.073)$ & $(0.083)$ & $(0.073)$ \\
\hline \multirow[t]{2}{*}{ Responsibility: Certainly yes } & $0.571 * * *$ & $0.444 * * *$ & $0.415 * * *$ & 0.078 & $0.276 * *$ \\
\hline & $(0.127)$ & $(0.124)$ & $(0.130)$ & $(0.148)$ & $(0.129)$ \\
\hline \multirow[t]{2}{*}{ Irregular working hours: Quite } & -0.007 & $0.160 * *$ & $0.219 * * *$ & 0.084 & $0.158 * *$ \\
\hline & $(0.079)$ & $(0.077)$ & $(0.079)$ & $(0.088)$ & $(0.079)$ \\
\hline \multirow[t]{2}{*}{ Irregular working hours: Certainly yes } & 0.016 & 0.121 & $0.496 * * *$ & 0.074 & $0.415 * * *$ \\
\hline & $(0.121)$ & $(0.118)$ & $(0.122)$ & $(0.140)$ & $(0.122)$ \\
\hline \multirow[t]{2}{*}{ Long working hours: Quite } & 0.113 & 0.086 & 0.097 & 0.037 & 0.122 \\
\hline & $(0.077)$ & $(0.074)$ & $(0.076)$ & $(0.084)$ & $(0.076)$ \\
\hline \multirow[t]{2}{*}{ Long working hours: Certainly yes } & -0.152 & 0.047 & -0.070 & $0.308 * *$ & $0.305 * * *$ \\
\hline & $(0.111)$ & $(0.107)$ & $(0.110)$ & $(0.129)$ & $(0.111)$ \\
\hline \multirow[t]{2}{*}{ Many worked years: Quite } & 0.025 & $0.150 * *$ & $0.248 * * *$ & $0.200 * *$ & $0.139 * *$ \\
\hline & $(0.070)$ & $(0.068)$ & $(0.070)$ & $(0.078)$ & $(0.070)$ \\
\hline \multirow[t]{2}{*}{ Many worked years: Certainly yes } & 0.003 & $0.216 * *$ & $0.545 * * *$ & $0.451 * * *$ & 0.109 \\
\hline & $(0.095)$ & $(0.091)$ & $(0.096)$ & $(0.115)$ & $(0.095)$ \\
\hline \multirow[t]{2}{*}{ Fictive person female } & $0.127 * *$ & $0.126 * *$ & $0.214 * * *$ & - & - \\
\hline & $(0.057)$ & $(0.056)$ & $(0.058)$ & & \\
\hline \multirow[t]{2}{*}{ Teacher ( self-identification ) } & $-0.215 * *$ & $0.426 * * *$ & $0.193 * *$ & 0.111 & 0.005 \\
\hline & $(0.089)$ & $(0.087)$ & $(0.090)$ & $(0.104)$ & $(0.090)$ \\
\hline \multirow[t]{2}{*}{ Nurse ( self-identification ) } & $-0.417 * * *$ & $-0.188 * *$ & 0.010 & -0.064 & -0.064 \\
\hline & $(0.082)$ & $(0.079)$ & $(0.082)$ & $(0.095)$ & $(0.082)$ \\
\hline \multirow[t]{2}{*}{ Construction worker ( self-identification) } & $-0.267 * *$ & $-0.283 * * *$ & $-0.345 * * *$ & 0.010 & $-0.191 *$ \\
\hline & $(0.110)$ & $(0.105)$ & $(0.108)$ & $(0.128)$ & $(0.108)$ \\
\hline \multirow[t]{2}{*}{ Fireman (self-identification ) } & $-0.244 *$ & -0.140 & -0.226 & 0.048 & $0.310 * *$ \\
\hline & $(0.143)$ & $(0.138)$ & $(0.142)$ & $(0.166)$ & $(0.145)$ \\
\hline \multirow[t]{2}{*}{$\sigma_{\vartheta}$} & \multicolumn{5}{|c|}{$0.610 * * *$} \\
\hline & \multicolumn{5}{|c|}{$(0.021)$} \\
\hline \multicolumn{2}{|l|}{ Log likelihood } & & -26494 & & \\
\hline Number of observations & & & 1771 & & \\
\hline
\end{tabular}

Standard errors in parentheses, *** Significant at $1 \%$ level, ** Significant at $5 \%$ level, $*$ Significant at $10 \%$ level. Baseline respondent answers the questions with a male name for the fictive person, self-identifies with having a desk job and considers the extent to which various job attributes make a job demanding to be 'certainly not', 'not really' or neutral. Background controls (gender, education, age, age squared, employment status and household income) are included. For complete results (including coefficients on background controls), see Appendix E. 
Table 2 Key estimation results for evaluation of the reasonable retirement age

\begin{tabular}{|c|c|c|c|c|c|}
\hline & \multicolumn{5}{|c|}{ Evaluation of reasonable retirement age } \\
\hline & (1) & (2) & (3) & $(4)$ & (5) \\
\hline & Desk job & Teacher & Nurse & Construction & Fireman \\
\hline & & & & Worker & \\
\hline \multirow[t]{2}{*}{$\gamma_{j}$} & $-0.552 * * *$ & $-0.815 * * *$ & $-0.836 * * *$ & $-0.738 * * *$ & $-0.960 * * *$ \\
\hline & $(0.036)$ & $(0.031)$ & $(0.032)$ & $(0.032)$ & $(0.030)$ \\
\hline \multirow{2}{*}{$\begin{array}{l}\text { Gender of fictive person } \\
\qquad(=1 \text { if female })\end{array}$} & $-0.258 * * *$ & $-0.248 * * *$ & $-0.241 * * *$ & - & - \\
\hline & $(0.080)$ & $(0.081)$ & $(0.082)$ & & \\
\hline \multirow[t]{2}{*}{ Teacher ( self-identification ) } & -0.091 & -0.061 & 0.052 & 0.031 & 0.021 \\
\hline & $(0.145)$ & $(0.147)$ & $(0.148)$ & $(0.152)$ & $(0.148)$ \\
\hline \multirow[t]{2}{*}{ Nurse (self-identification ) } & -0.129 & -0.175 & -0.211 & -0.142 & -0.100 \\
\hline & $(0.132)$ & $(0.133)$ & $(0.134)$ & $(0.138)$ & $(0.135)$ \\
\hline \multirow[t]{2}{*}{ Construction Worker (self-identification) } & -0.056 & 0.029 & -0.110 & 0.228 & -0.099 \\
\hline & $(0.185)$ & $(0.186)$ & $(0.187)$ & $(0.193)$ & $(0.188)$ \\
\hline \multirow[t]{2}{*}{ Fireman ( self-identification ) } & 0.052 & -0.283 & -0.253 & 0.010 & 0.032 \\
\hline & $(0.242)$ & $(0.243)$ & $(0.245)$ & $(0.252)$ & $(0.248)$ \\
\hline \multirow[t]{2}{*}{$\sigma_{\varepsilon}$} & \multicolumn{5}{|c|}{$1.365 * * *$} \\
\hline & \multicolumn{5}{|c|}{$(0.010)$} \\
\hline \multirow[t]{2}{*}{$\sigma_{\rho}$} & \multicolumn{5}{|c|}{$1.587 * * *$} \\
\hline & \multicolumn{5}{|c|}{$(0.03)$} \\
\hline \multirow[t]{2}{*}{$\tau$ ( correlation coefficient) } & \multicolumn{5}{|c|}{0.051} \\
\hline & \multicolumn{5}{|c|}{$(0.033)$} \\
\hline Log likelihood & \multicolumn{5}{|c|}{-26494} \\
\hline Number of observations & \multicolumn{5}{|c|}{1771} \\
\hline standard deviation ( $s d$ ) increase in & $-0.751 * * *$ & $-1.042 * * *$ & $-1.118 * * *$ & $-1.066 * * *$ & $-1.254 * * *$ \\
\hline demanding occupation $\left(=\gamma_{j} * s d\right)$ & $(0.050)$ & 39) & $42)$ & $(0.046)$ & $(0.040)$ \\
\hline
\end{tabular}

Standard errors in parentheses, *** Significant at $1 \%$ level, ** Significant at $5 \%$ level, * Significant at $10 \%$ level. Baseline respondent has a desk job and answers the questions with a male name for the fictive person. Background controls (gender, education, age, age squared, employment status and household income) are included. For full set of results (including background controls), see Appendix E. The bottom row shows $\gamma_{j} * s d$

Alternatively, combining Tables 1 and 2, the estimates imply that the reasonable retirement age for a construction worker decreases by 1.6 years if the respondent thinks physical work certainly makes an occupation demanding compared to when the respondent does not think physical work makes a job demanding. ${ }^{14}$

Female fictive persons are allowed to retire about three months earlier than male fictive persons who have the same job and whose job is evaluated as equally demanding. Keeping all other variables constant (including $y^{*}$ ) construction workers are allowed to retire at the earliest age. Self-identification with the occupations of the fictive persons

\footnotetext{
${ }^{14}$ This is the difference between answering the highest category ('most certainly') and the three lowest categories ('certainly not', 'not really' or 'neutral'). Table 1 shows the effect on $y^{*}: 2.195$. This leads to ab effect $\gamma_{j} * 2.195=$ $-0.738 * 2.195=-1.62$ years, ceteris paribus.
} 
seems to be unimportant here, as none of the coefficients is significant at the $5 \%$ level. Still, there is an indirect effect: Self-identification influences how demanding occupations are, and this affects the reasonable retirement age of an occupation - as indicated by the significant $\gamma$-coefficients. Combining the direct and indirect effect, the largest effect of selfidentification is found for teachers evaluating teachers. Compared to other respondents, teachers think teachers should be able to retire about five months earlier, because teachers and non-teachers have a different view on the demanding nature of the occupation of a teacher. Those who identify with another occupation also often tend to support earlier retirement for that occupation, but these effects are much smaller.

Unobserved heterogeneity is significant in both equations. In equation 1, the estimated standard deviation of the unobserved heterogeneity terms is 0.61 (Table 1), while the standard deviation of the idiosyncratic error term, which is equal to one (by normalization). In equation 3, the error term has estimated standard deviation 1.37, whereas the standard deviation of the unobserved heterogeneity term amounts to 1.59 ( Table 2). The unobserved heterogeneity terms are slightly positively correlated, but the correlation is not significant.

In a robustness check, we included the opinion of the respondents about the increase of the statutory retirement age in the Netherlands as an additional regressor, since such an opinion could matter for what respondents consider reasonable retirement ages. For instance, respondents who disagree with this reform might indicate that each fictive person should be allowed to retire early. In a previous survey, the same respondents were asked to choose amongst several measures to make the first pillar pension scheme sustainable. The measures included lower benefits, a higher pension premium, and an increase in the statutory retirement age. Appendix $G$ lists the exact question and the distribution of the answers, as well as the complete estimates of a full model in which the answer to this question is added on the right hand side of the equation for the reasonable retirement age. These results show that, as expected, respondents who think that the statutory retirement age should be increased also give higher reasonable retirement ages than respondents who prefer other measures. Inclusion of this in the model, however, does not change any of the results on the variables of interest. 


\subsection{Demanding occupations and willingness to contribute to an early retirement scheme}

In this section, we model the relationship between the extent to which an occupation is perceived to be demanding and whether respondents are willing to contribute to an early retirement scheme for that occupation by paying additional (income) taxes. This model closely resembles the model of the previous section. Respondents $(i=1, \ldots, N)$ evaluate how demanding certain occupations $(j=1, \ldots, 5)$ are according to equations 1 and 2 . The extent to which they are willing to contribute to an early retirement scheme for these professions, with five ordered possible answers, is also modeled using an ordered response equation:

$$
\begin{aligned}
& C_{i j}^{*}=\kappa_{j} y_{i j}^{*}+X_{i}^{\prime} \mu_{j}+Z_{i} \eta_{j}+\phi_{i}+\psi_{i j} \\
& C_{i j}=l \text { if } d_{l-1}<C_{i j}^{*} \leq d_{l} \\
& \text { with } 1 \leq l \leq 5, d_{0}=-\infty \text { and } d_{5}=\infty
\end{aligned}
$$

The willingness to contribute to an early retirement scheme $C_{i j}^{*}$ for respondent $i$ and occupation $j$ depends on the same variables as in equation 3 , including the perceived demands of occupation $j$. The respondent specific unobserved heterogeneity term in this equation is denoted by $\phi_{i}$. The idiosyncratic error $\psi_{i j}$ is assumed to follow a standard normal distribution.

Since unobserved individual characteristics explaining the opinion about demanding occupations could be related to those determining the willingness to contribute to an early retirement scheme, we assume, the two unobserved heterogeneity terms are bivariate normal, independent of the covariates:

$$
\left(\begin{array}{l}
\vartheta_{i} \\
\phi_{i}
\end{array}\right) \sim N\left(\left(\begin{array}{c}
0 \\
0
\end{array}\right),\left(\begin{array}{cc}
\sigma_{\vartheta}^{2} & \omega \sigma_{\phi} \sigma_{\vartheta} \\
\omega \sigma_{\phi} \sigma_{\vartheta} & \sigma_{\phi}^{2}
\end{array}\right)\right) .
$$

This implies a correlation between the unobservables equations 1 and 5 if the parameter $\omega$ is not equal to zero. Equations 1, 2, 5 and 6 are estimated simultaneously using Simulated Maximum Likelihood with 100 Halton draws (see Cappelari and Jenkins, 2006). ${ }^{15}$ Appendix C provides details of the likelihood.

\footnotetext{
${ }^{15} \mathrm{~A}$ higher number of draws hardly affects the estimates.
} 
Table 3 presents the results. If respondents find an occupation more demanding, they are also willing to contribute more to an early retirement scheme for that occupation $\left(\kappa_{j}\right) .{ }^{16}$ Table 4 shows the implied marginal effects on the probability to answer "probably yes" or "certainly yes". It shows an average respondent is 28 to 39 percentage points more likely to contribute to the early retirement scheme if the extent to which the occupation under consideration is more demanding increases by one standard deviation.

Table 3 Key estimation results for the willingness to contribute to (early) retirement schemes

\begin{tabular}{|c|c|c|c|c|c|}
\hline & \multicolumn{5}{|c|}{ Evaluation of willingness to contribute } \\
\hline & (1) & $(2)$ & ( 3 ) & (4) & ( 5 ) \\
\hline & Desk job & Teacher & Nurse & Construction & Fireman \\
\hline & & & & Worker & \\
\hline \multirow[t]{2}{*}{$\kappa_{j}$} & $1.492 * * *$ & $1.294 * * *$ & $0.766 * * *$ & $0.564 * * *$ & $0.654 * * *$ \\
\hline & $(0.073)$ & $(0.060)$ & $(0.042)$ & $(0.037)$ & $(0.035)$ \\
\hline \multirow{2}{*}{$\begin{array}{l}\text { Gender of fictive person } \\
\qquad(=1 \text { if female })\end{array}$} & -0.123 & -0.014 & 0.126 & - & - \\
\hline & $(0.093)$ & $(0.086)$ & $(0.078)$ & & \\
\hline \multirow[t]{2}{*}{ Teacher ( self-identification ) } & 0.149 & -0.061 & -0.021 & -0.059 & -0.032 \\
\hline & $(0.189)$ & $(0.185)$ & $(0.184)$ & $(0.189)$ & $(0.185)$ \\
\hline \multirow[t]{2}{*}{ Nurse ( self-identification ) } & $0.716 * * *$ & $0.333 * *$ & $0.375 * *$ & $0.421 * *$ & $0.370 * *$ \\
\hline & $(0.175)$ & $(0.168)$ & $(0.168)$ & $(0.173)$ & $(0.170)$ \\
\hline \multirow[t]{2}{*}{ Construction Worker ( self-identification) } & 0.381 & 0.364 & $0.545 * *$ & $0.656 * * *$ & $0.590 * *$ \\
\hline & $(0.239)$ & $(0.232)$ & $(0.231)$ & $(0.237)$ & $(0.232)$ \\
\hline \multirow[t]{2}{*}{ Fireman ( self-identification ) } & $0.552 *$ & 0.235 & 0.463 & 0.198 & 0.468 \\
\hline & $(0.302)$ & $(0.293)$ & $(0.290)$ & $(0.297)$ & $(0.293)$ \\
\hline \multirow[t]{2}{*}{ Constant } & - & -0.749 & -0.966 & -0.304 & -0.003 \\
\hline & & $(0.578)$ & $(0.606)$ & $(0.653)$ & $(0.630)$ \\
\hline \multirow[t]{2}{*}{$\sigma_{\phi}$} & \multicolumn{5}{|c|}{$2.731 * * *$} \\
\hline & \multicolumn{5}{|c|}{$(0.077)$} \\
\hline \multirow[t]{2}{*}{$\omega($ correlation coefficient) } & \multicolumn{5}{|c|}{$0.516 * * *$} \\
\hline & \multicolumn{5}{|c|}{$(0.021)$} \\
\hline number of observations & \multicolumn{5}{|c|}{1771} \\
\hline Log likelihood & \multicolumn{5}{|c|}{-18096} \\
\hline
\end{tabular}

Standard errors in parentheses. *** Significant at 1\% level, ** Significant at 5\% level, * Significant at 10\% level. Baseline respondent self-identifies their job with a desk job and has a male name for the fictive person in answering the questions. Background controls (gender, education, age, age squared, employment status and household income) are included. For complete results (including background controls), see Appendix F.

Unobserved heterogeneity is significantly present. Table 3 shows that the standard deviation of the willingness to contribute amounts to 2.73 , while the standard deviation of the idiosyncratic error term is normalized to 1. Moreover, a sizeable and significant correlation

\footnotetext{
${ }^{16}$ The estimates of the coefficients in equation 1 are very similar to those in Table 1 (also see appendix F) and therefore not presented here.
} 
between the two unobserved heterogeneity terms of 0.52 is found. This indicates that respondents with a higher general willingness to contribute typically also tend to evaluate occupations as more demanding.

Table 3 also shows that, keeping other variables (including $y^{*}$ ) constant, selfidentification with a teacher or a fireman does not lead to a higher willingness to contribute for any other occupation compared to self-identification with having a desk job. Nurses are the other extreme case: if respondents have an occupation similar to that of a nurse, they are willing to contribute to an early retirement scheme of every occupation.

Table 4 Impact of one standard deviation increase in the perceived demanding nature of an occupation $\left(y^{*}\right)$ on willingness to contribute to early retirement scheme

\begin{tabular}{ccccc}
\hline $\begin{array}{c}\text { Desk } \\
\text { Job }\end{array}$ & Teacher & Nurse & $\begin{array}{c}\text { Construction } \\
\text { worker }\end{array}$ & $\begin{array}{c}\text { Fire } \\
\text { man }\end{array}$ \\
$28.38 * * *$ & $39.44 * * *$ & $38.12 * * *$ & $33.03 * * *$ & $33.70 * * *$ \\
$(1.38)$ & $(1.83)$ & $(2.09)$ & $(2.18)$ & $(1.78)$
\end{tabular}

Standard errors in parentheses. *** Significant at $1 \%$ level, ** Significant at $5 \%$ level, $*$ Significant at $10 \%$ level. Each marginal effect is evaluated for the proportion of the sample that considers the occupation in the column to be somewhat demanding or demanding. Numbers are in percentage points. The baseline respondent has a job similar to a desk job and has a male name for the fictive person in answering the questions.

Construction workers are willing to contribute significantly more than respondents with a desk job to retirement schemes of nurses, construction workers and firemen. The combinations of direct and indirect effects are presented in Table 5. It shows that, overall, respondents tend to be more willing to contribute to retirement schemes for a given occupation if that occupation resembles their own. They then probably expect to benefit themselves from such arrangements. ${ }^{17}$

We can conclude that self-identification plays some role, but to what extent does it explain the overall support for early retirement schemes? Figure 6 shows whether people are willing to contribute to retirement schemes of occupations that are not similar to their own occupation. Almost half of the respondents not identifying themselves with construction

\footnotetext{
17 Re-estimation of this model with the opinion about the pension reform in the Netherlands as an additional regressor gives virtually the same results. See appendix G.
} 
worker indicate that they are probably or certainly willing to contribute to an early retirement scheme for construction workers. The willingness to contribute to such a scheme is somewhat smaller for firemen among non-firemen, and substantially smaller for the other three occupations (among those who do not identify with that occupation). Only 6 percent of the respondents not in a desk job are probably or certainly willing to contribute to an early retirement scheme of office clerks. Respondents are apparently willing to contribute to the retirement schemes of other occupations, but only if they perceive the occupations as demanding.

Table 5 Marginal effects of self-identification on the willingness to contribute to (early) retirement schemes

\begin{tabular}{|c|c|c|c|c|}
\hline \multirow[b]{2}{*}{$\begin{array}{c}\text { Evaluation of the fictive } \\
\text { person as: }\end{array}$} & \multicolumn{4}{|c|}{ Self-identifies with: } \\
\hline & Teacher & Nurse & Construction worker & Fireman \\
\hline \multirow[t]{2}{*}{ Desk job } & -2.03 & 2.43 & -0.03 & 4.72 \\
\hline & $(3.27)$ & $(3.01)$ & $(4.08)$ & $(5.22)$ \\
\hline \multirow[t]{2}{*}{ Teacher } & $12.71 * *$ & 3.30 & 1.05 & 3.94 \\
\hline & $(5.00)$ & $(4.70)$ & $(6.33)$ & $(8.02)$ \\
\hline \multirow[t]{2}{*}{ Nurse } & 5.51 & $15.72 * *$ & 11.15 & 12.80 \\
\hline & $(7.47)$ & $(6.87)$ & $(9.38)$ & $(11.85)$ \\
\hline \multirow[t]{2}{*}{ Construction worker } & 0.35 & $16.19 * *$ & $27.17 * * *$ & 9.85 \\
\hline & $(7.84)$ & $(7.20)$ & $(9.77)$ & $(12.36)$ \\
\hline \multirow[t]{2}{*}{ Fireman } & -0.56 & $13.54 *$ & $19.05 * *$ & $28.53 * *$ \\
\hline & $(7.76)$ & $(7.14)$ & $(9.72)$ & $(12.31)$ \\
\hline
\end{tabular}

Standard errors in parentheses, *** Significant at 1\% level, ** Significant at 5\% level, * Significant at $10 \%$ level. The magnitude of the marginal effect evaluated for the proportion of the sample that considers the occupation in the row to be demanding or very demanding. Numbers in percentage points. Benchmark: respondents self-identifying with having a desk job.

This finding is in line with the support for policies that rely on reciprocity found by Fong et al. ( 2005 ; cf. Section 2 ). An interpretation is that many respondents think that workers in physically demanding occupations contribute to society at the cost of their own health, and that compensation for this is justified. Earlier retirement is an attractive form of compensation since for workers in physically demanding occupations, both deteriorated health and the nature of their job make it difficult to continue working at an older age. Perugini et al. (2003) describe questions to measure individuals' reciprocity and have validated these questions in experiments. It would be interesting to see whether individuals who are reciprocal according to their index are indeed more willing to contribute to the 
early retirement schemes of demanding occupations, but our current data do not contain the reciprocity index.

Figure 6 Respondents willing to contribute to retirement schemes of occupations other than their own

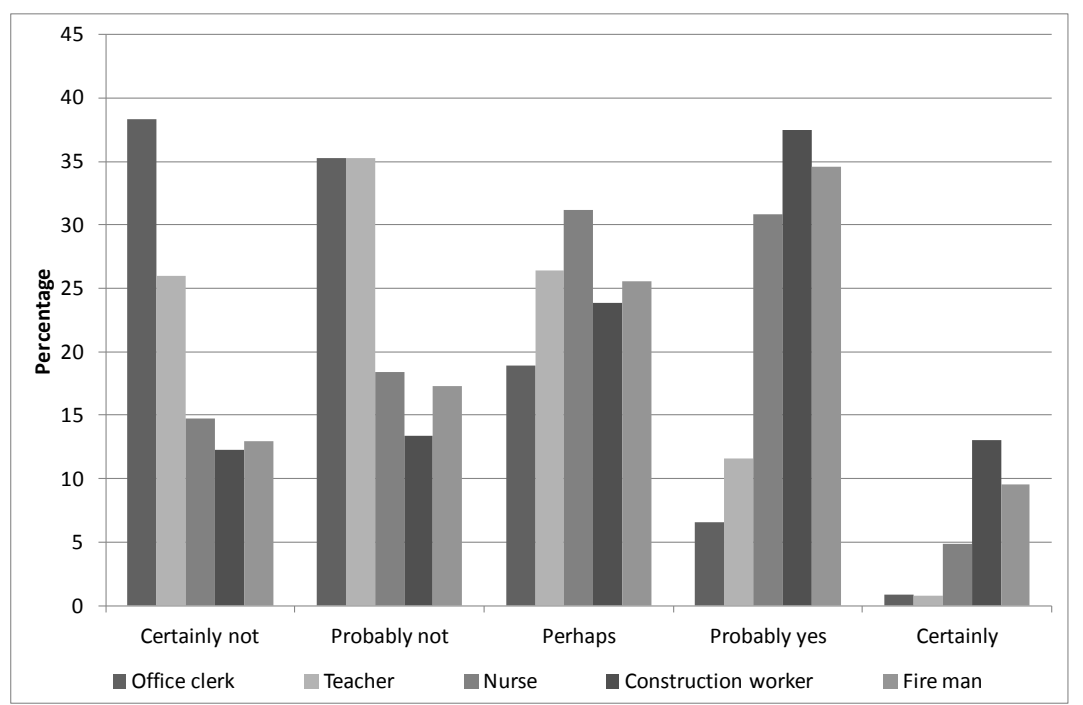

For the evaluation of the willingness to contribute for the occupations, respondents with the same occupation are omitted. For instance, in the evaluation of office clerk the respondents self-identifying with office clerks are left out. Source: descriptive statistics (DO), own computations

\section{Conclusion}

This paper relates perceptions of what makes an occupation demanding to what people consider a reasonable retirement age and the willingness to contribute to an early retirement schemes for specific occupations. This is motivated by the policy debate on differentiating the retirement benefits eligibility age by making an exception for demanding occupations. Such a debate took place in the Netherlands a few years ago and is now taking place in other countries.

Our first main finding is that the Dutch generally think that high physical burden make an occupation demanding, while mental aspects such as time pressure or a lot of responsibility are much less important. Accordingly, they evaluate the occupations construction worker and firefighter as much more demanding than teacher or desk job. Second, the Dutch think it is justified that a worker in a demanding occupation can retire approximately two years earlier than someone whose occupation is not demanding. This difference is equal to the increase in the statutory retirement age in the Netherlands for 
the coming years. Third, the survey indicates that the Dutch are willing to contribute to an early retirement scheme for (physically) demanding occupations by paying higher income taxes. Although we do find effects of self-identification, the support and willingness to contribute remain substantial when correcting for self-identification: Individuals are often also willing to contribute to the retirement schemes of demanding occupations that are not similar to their own occupation. For instance, almost half of the respondents who do not identify themselves with construction worker indicate that they are probably or certainly willing to contribute to a retirement scheme for construction workers.

What do our findings imply for public policy? As discussed in Section 1, a debate on differentiation of the eligibility age for the Dutch first pillar state pensions took place but ended with the conclusion that implementation of such a policy was infeasible in practice. Moreover, it might reduce incentives for employers to invest in new technology or other ways to keep people at work longer. It also might lead to strategic behavior of employees who can switch occupations at a later age to qualify for earlier retirement (Ravesteijn et al., 2013). Alternatively, it could prevent workers in demanding occupations to change to a less demanding job at a later age, increasing labor market rigidity. On the other hand, the suggested solution of repairing the gap in first pillar pensions through the second pillar is expensive, particularly for employees in poorly paid physically demanding jobs who largely rely on the state pension.

An alternative policy would be to make the first pillar eligibility age a function of the number of years worked over the lifetime, possibly with adjustment for, e.g., involuntary unemployment, disability, or career interruptions due to young children. This is the system recently introduced in Germany (OECD, 2013, p. 257), where the statutory retirement age is 67 but people with 45 years of insured employment can retire at age 65 without benefit reduction (or even at age 63 but then with reduced benefits). ${ }^{18}$ Such a policy is easier to implement and induces less problems concerning strategic behavior. Individuals with physically demanding occupations would benefit from such an arrangement, since they often have low education level and start working at a relatively early age.

\footnotetext{
18 In case of a serious disability, early retirement in Germany can start at age 60.
} 
Similar policies could also use other proxies to differentiate the statutory retirement age, such as (lifetime) income.

It is important to note, however, that such policies also entail costs. For instance, a lower retirement age for demanding occupations may lead to a shift from disability at the end of working life to early retirement. This could diminish incentives for the employer to make occupations less demanding, for example by reducing heavy lifting or hazardous or stressful activities, as employers might find it easier or cheaper to redirect their employees into early retirement than to apply for disability. It is up to policy makers to strike a balance in this trade-off. Further research is needed to evaluate the advantages and drawbacks of such policies. These may depend on the nature of the pension system and what may be optimal in the German setting is not necessarily optimal in other countries.

Finally, more research seems warranted on alternative (supplementary) policies. Investing in the technological improvement of demanding occupations, increasing flexibility of the job market at later ages, or pricing compensating differentials differently, are some of the candidates. The efficiency of such policies, possibly in combination with a policy of differentiated statutory retirement ages, remains unstudied so far. 


\section{References}

Andreoni, J., 2006, Philanthropy, in S. Kolm and J.M. Ythier, Handbook of the Economics of Giving, Altruism and Reciprocity, Volume 2, Amsterdam: Elsevier, 1201 1269

Böckerman, P. and P. Ilmakunnas, 2006, Do job disamenities raise wages or ruin job satisfaction?, International Journal of Manpower, 27(3), 290-302

Böckerman, P., P. Ilmakunnas and E. Johansson, 2011, Job security and employee wellbeing: Evidence from matched survey and register data, Labour Economics, 18(4), 547 $-554$

Boeri, T., A. Boersch-Supan and G. Tabellini, 2002, Pension reforms and the opinions of European citizens, American Economic Review, 92(2), 396-401.

Boldrin, M., S. Jimenez-Martin and F. Peracchi, 2004, Micro-modeling of retirement behavior in Spain, in J. Gruber and D. Wise (eds.), Social Security and Retirement Behavior Around the World: Micro- Estimation, Chicago: University of Chicago Press, $499-578$

Borghans, L. and B. ter Weel, 2012, Zware dilemma's voor zware beroepen, Demos, 28(10), 5-8

Bovenberg, A.L., J. Mackenbach and R. Mehlkopf, 2006, Een eerlijk en vergrijzingbestendig ouderdomspensioen, Economisch-Statistische Berichten, 91(4500), $648-651$

Bryson, A., E. Barth and H. Dale-Olsen, 2012, Do higher wages come at a price?, Journal of Economic Psychology, 33(1), 251 - 263

Cappellari, L. and S. Jenkins, 2006, Calculation of Multivariate Normal Probabilities by Simulation, with Applications to Maximum Simulated Likelihood Estimation, IZA Discussion Paper No. 2112

Case, A. and A. Deaton, 2005, Broken Down by Work and Sex: How Our Health Declines, in D. Wise, Analysis in the Economics of Aging, Chicago: University of Chicago Press, $185-212$

Charness, G. and M. Rabin, 2002, Understanding social preferences with simple tests, Quarterly Journal of Economics, 117 (3), 817-869 
Cremer, H. and P. Pestieau, 2000, Reforming our pension system: is it a demographic, financial, or political problem?, European Economic Review, 44(4-6), 974-983

Datta Gupta, N., D. Lau and D. Pozzoli, 2012, The impact of education and occupation on temporary and permanent work incapacity, IZA Discussion Paper No. 7240

De Grip, A., D. Fouarge and R. Montizaan (2013), How sensitive are individual retirement expectations to raising the retirement age?, De Economist, 161, 225-251.

DellaVigna, S., 2009, Psychology and Economics: Evidence from the field, Journal of Economic Literature, $47(2), 315-372$

Fehr, E. and S. Gächter, 2000, Fairness and Retaliation: The Economics of Reciprocity, Journal of Economic Perspectives, 14(3), 159 - 181

Fehr, E. and K.M. Schmidt, 2006, The economics of fairness, reciprocity and altruism experimental evidence and new theories, In S. Kolm and J. Ythier, Handbook of the Economics of Giving, Altruism and Reciprocity, Volume 1, Amsterdam: Elsevier, 615-691

Filer, R.K. and P.A. Petri, 1988, A job-characteristics theory of retirement, Review of Economics and Statistics, 70(1), 123-128.

Fletcher, J.M., J.L. Sindelar and S. Yamaguchi, 2011, Cumulative effects of job characteristics on health, Health Economics, 20(5), 553-570

Fong, C.M., S. Bowles and H. Gintis, 2005, Behavioural motives for income redistribution, Australian Economic Review, 38(3), 285-297

García-Gómez, P., H.M. von Gaudecker and M. Lindeboom, 2011, Health, disability and work: patterns for the working age population, International Tax Public Finance, 18(2), $146-165$

Grossman, M., 1972, On the concept of health capital and the demand for health, Journal of Political Economy, 80(2), 223 - 255

Gruber, J. and D.A. Wise, 1999, Social Security and Retirement around the World, Chicago: University of Chicago Press

Gruber, J., and D.A. Wise, 2004, Social Security Programs around the World: Micro Estimation, Chicago: University of Chicago Press 
Gustman, A., and Th. Steinmeier, 2005, The social security early retirement age in a structural model of retirement and wealth, Journal of Public Economics, 89(2), 441463

Holden, K., 1988, Physically demanding occupations, health, and work after retirement: Findings from the New Beneficiary Survey, Social Security Bulletin, 51(11), 3-15 Jaime-Castillo, A. M., 2013, Public opinion and the reform of the pension systems in Europe: the influence of solidarity principles, Journal of European Social Policy, 23: $390-405$

Joulain, M. and E. Mullet, 2001, Estimating the 'appropriate' age for retirement as a function of perceived occupational characteristics, Work \& Stress: An International Journal of Work, Health \& Organisations, 15(4), 357-365

Kalwij, A.S., R.J. Alessie and M.G. Knoef, 2013, The association between individual income and remaining life expectancy at the age of 65 in the Netherlands, Demography, $50(1), 181-206$

Majer, I.M., R. Stevens, W.J. Nusselder, J.P. Mackenbach and P.H. van Baal, 2013, Modeling and forecasting health expectancy: theoretical framework and an application, Demography, 50(2), 673-697

Ministry of Social Affairs and Employment, 2013, Inkomen en Vermogen van Ouderen: Analyse en Beleidsopties, IBO rapport, http://www.rijksoverheid.nl/documenten-enpublicaties/rapporten/2013/09/13/ibo-rapport-inkomen-en-vermogen-van-ouderenanalyse-en-beleidsopties.html

Neumark, D. and J. Song, 2012, Barriers to later retirement: Increases in the full retirement age, age discrimination, and the physical challenges of work, Michigan Retirement Research Center Working Paper 2012-265

O'Donnell, O. and P. Tinios, 2003, The politics of pension reform: lessons from public attitudes in Greece, Political Studies, 51(2), 262-281

OECD, 2007, OECD Economic surveys: Greece 2007, OECD Publishing, Paris, http://dx.doi.org/10.1787/eco_surveys-grc-2007-en

OECD, 2011, Pensions at a Glance 2011: Retirement-income Systems in OECD and G20 Countries, OECD Publishing, Paris, http://dx.doi.org/10.1787/pension_glance-2011-en 
OECD, 2013, Pensions at a Glance 2013: OECD and G20 Indicators, OECD Publishing, Paris, http://dx.doi.org/10.1787/pension_glance-2013-en

Perugini, M., M. Gallucci, F. Presaghi and A. Ercolani, 2003, The personal norm of reciprocity, European Journal of Personality, 17(4), 251-283

Ravesteijn, B., H. van Kippersluis and E. van Doorslaer, 2013, Long and healthy careers? The relationship between occupation and health and its implications for the statutory retirement age, Netspar Panel paper 36

Rust, J., and C. Phelan, 1997, How Social Security and Medicare affect retirement behavior in a world of incomplete markets, Econometrica, 65(4), 781-831

Sindelar, J.L., J. Fletcher, T. Falba, P. Keenan and W.T. Gallo, 2007, Impact of first occupation on health at older ages, National Bureau of Economic Research Working Paper 13715

Tyran, J. R. and R. Sausgruber, 2006, A little fairness may induce a lot of redistribution in democracy, European Economic Review, 50(2), 469-485

Van Groezen, B., H. Kiiver and B. Unger, 2009. Explaining Europeans' preferences for pension provision, European Journal of Political Economy, 25(2), 237-246

Van Solinge, H. and K. Henkens, 2008, Adjustment to and satisfaction with retirement: Two of a kind?, Psychology and Aging, 23(2), 422 - 434 


\section{Appendix A. Survey questions}

This appendix lists the questions of the survey on demanding occupations. First, the respondents were asked what they thought was a reasonable retirement age for five fictive persons with different occupations:

We would like to ask you a number of hypothetical questions about the retirement age for various occupations. These questions are not about you, but about fictive persons with some given characteristics. We would like to hear your opinion these persons. John, Henry, Tim, Klaas and Stijn [in case of female names for the first three occupations: Joan, Maria, Ann] are all 55 years of age. They have worked full-time for the last 30 years. Before that, they went to school. Their salaries are all the same.

- John [or Joan] has worked for 30 years at a desk job. What do you think is a reasonable retirement age for John [or Joan]?

- Henry [or Maria] has taught for 30 years at an elementary school. What do you think is a reasonable retirement age for Henry [or Maria]?

- Tim [or Ann] has worked as a nurse for the last 30 years. What do you think is a reasonable retirement age for Tim [or Ann]?

- Klaas has worked for 30 years in the construction sector. What do you think is a reasonable retirement age for Klaas?

- Stijn has worked for 30 years as a fireman. What do you think is a reasonable retirement age for Stijn?

Answer categories for all these questions: Younger than 60 years of age / 60 years of age / 61 years of age /.... / 70 years of age/Older than 70 years of age

We would now like to ask you some questions about your willingness to contribute to early retirement schemes for certain occupations. This means that people with certain occupations will have the opportunity to retire earlier than people with other occupations.

Are you willing to contribute as a tax payer to an early retirement scheme for the persons we just described?

- John [or Joan] (has a desk job)

- Henry [or Maria] (teacher at an elementary school)

- $\operatorname{Tim}$ [or Ann] (nurse)

- Klaas (Construction worker) 
- Stijn (Fireman)

Answer categories for all these questions: Certainly not / Probably not / Perhaps / Probably yes / Certainly yes

Do you think that the following persons have a demanding occupation?

- John [or Joan] (has a desk job)

- Henry [or Maria] (teacher at an elementary school)

- $\operatorname{Tim}[o r$ Ann] (nurse)

- Klaas (Construction worker)

- Stijn (Fireman)

Answer categories for all these questions: Undemanding / Somewhat undemanding / Not undemanding, not demanding / Somewhat demanding / Demanding

What attributes makes an occupation demanding in your view?

- Working in shifts

- Physically demanding

- Working under time pressure (work has to be finished within a certain period)

- A lot of responsibility

- Irregular working hours

- Long working days

- Many worked years (in some occupations it is common to have started working at 16 or 18 years of age)

Answer categories for all these questions: Certainly not / not really / neutral / quite / Most certainly

To the persons indicating they have a job or had a job before, the following question was asked: With which person does your occupation most closely compare? John [or Joan] (has a desk job) / Henry [or Maria] (teacher at an elementary school) / Tim [or Ann] (nurse) / Klaas (Construction worker) / Stijn (Fireman) 


\section{Appendix B. Likelihood function for model of demanding occupations and}

\section{reasonable retirement age}

This appendix derives the likelihood function of the model in section 4.1. The probability density corresponding to equation (4) is:

$$
g\left(R_{i j}=r_{i j} \mid W_{i j}, X_{i}, Z_{i}, \rho_{i}, \vartheta_{i}\right)=\frac{1}{\sqrt{\sigma_{\varepsilon}^{2}+\gamma_{j}^{2}}} \varphi\left(\frac{r_{i j}-W_{i j}^{\prime} \gamma_{j} \lambda_{j}-X_{i}^{\prime}\left(\gamma_{j} \delta_{j}+\eta_{j}\right)-Z_{i}\left(\beta_{j}+\alpha_{j} \gamma_{j}\right)-\rho_{i}-\gamma_{j} \vartheta_{i}}{\sqrt{\sigma_{\varepsilon}^{2}+\gamma_{j}^{2}}}\right)
$$

Equations (1) and (2) combine into:

$$
\begin{gathered}
Y_{i j}=1 \text { if } Y_{i j}^{*} \leq c_{1}-X_{i}^{\prime} \delta_{j}-Z_{i} \alpha_{j}-W_{i j}^{\prime} \lambda_{j}-\vartheta_{i} \\
Y_{i j}=2 \text { if } c_{1}-X_{i}^{\prime} \delta_{j}-Z_{i} \alpha_{j}-W_{i j}^{\prime} \lambda_{j}-\vartheta_{i}<Y_{i j}^{*} \leq c_{2}-X_{i}^{\prime} \delta_{j}-Z_{i} \alpha_{j}-W_{i j}^{\prime} \lambda_{j}-\vartheta_{i} \\
Y_{i j}=3 \text { if } c_{2}-X_{i}^{\prime} \delta_{j}-Z_{i} \alpha_{j}-W_{i j}^{\prime} \lambda_{j}-\vartheta_{i}<Y_{i j}^{*} \leq c_{3}-X_{i}^{\prime} \delta_{j}-Z_{i} \alpha_{j}-W_{i j}^{\prime} \lambda_{j}-\vartheta_{i} \\
Y_{i j}=4 \text { if } c_{3}-X_{i}^{\prime} \delta_{j}-Z_{i} \alpha_{j}-W_{i j}^{\prime} \lambda_{j}-\vartheta_{i}<Y_{i j}^{*} \leq c_{4}-X_{i}^{\prime} \delta_{j}-Z_{i} \alpha_{j}-W_{i j}^{\prime} \lambda_{j}-\vartheta_{i} \\
Y_{i j}=5 \text { if } Y_{i j}^{*}>c_{4}-X_{i}^{\prime} \delta_{j}-Z_{i} \alpha_{j}-W_{i j}^{\prime} \lambda_{j}-\vartheta_{i}
\end{gathered}
$$

For the construction of the individual likelihood contribution the associated probability of equation (1) is conditioned on $\varepsilon_{i j}+\gamma_{j} u_{i j}$. This conditional distribution is normal: $u_{i j} \mid\left(\varepsilon_{i j}+\right.$ $\left.\gamma_{j} u_{i j}\right) \sim N\left(\frac{1}{\sigma_{\varepsilon}} \frac{\gamma_{j}}{\sqrt{\sigma_{\varepsilon}^{2}+\gamma_{j}^{2}}}\left(\varepsilon_{i j}+\gamma_{j} u_{i j}\right), 1-\frac{\gamma_{j}^{2}}{\sigma_{\varepsilon}^{2}+\gamma_{j}^{2}}\right)$ and leads to the following equation:

$$
\begin{aligned}
P\left(Y_{i j}=k \mid W_{i j}, X_{i}, Z_{i}, \vartheta_{i}, \varepsilon_{i j}+\gamma_{j} u_{i j}\right) & \left(\frac{\mathrm{c}_{k}-X_{i}^{\prime} \delta_{j}-Z_{i} \alpha_{j}-W_{i j}^{\prime} \lambda_{j}-\vartheta_{i}-\frac{1}{\sigma_{\varepsilon}} \frac{\gamma_{\mathrm{j}}}{\sqrt{\sigma_{\varepsilon}^{2}+\gamma_{\mathrm{j}}^{2}}}\left(\varepsilon_{i j}+\gamma_{j} u_{i j}\right)}{\sqrt{1-\frac{\gamma_{\mathrm{j}}^{2}}{\sigma_{\varepsilon}^{2}+\gamma_{\mathrm{j}}^{2}}}}\right) \\
& -\Phi\left(\frac{\mathrm{c}_{k-1}-X_{i}^{\prime} \delta_{j}-Z_{i} \alpha_{j}-W_{i j}^{\prime} \lambda_{j}-\vartheta_{i}-\frac{1}{\sigma_{\varepsilon}} \frac{\gamma_{\mathrm{j}}}{\sqrt{\sigma_{\varepsilon}^{2}+\gamma_{j}^{2}}}\left(\varepsilon_{i j}+\gamma_{j} u_{i j}\right)}{\sqrt{1-\frac{\gamma_{\mathrm{j}}^{2}}{\sigma_{\varepsilon}^{2}+\gamma_{\mathrm{j}}^{2}}}}\right)
\end{aligned}
$$

for $k=1, \ldots, 5$

As before, we define for notational purposes: $c_{0}=-\infty$ and $c_{5}=\infty$

Equation (4) can be rewritten to give an expression for the residuals and inserted in equation (B.2), leading to equation (B.3): 


$$
\begin{aligned}
& P\left(Y_{i j}=k \mid W_{i j}, X_{i}, Z_{i}, \vartheta_{i}, \varepsilon_{i j}+\gamma_{j} u_{i j}\right) \\
& =\Phi\left(\frac{\mathrm{c}_{k}-X_{i}^{\prime} \delta_{j}-Z_{i} \alpha_{j}-W_{i j}^{\prime} \lambda_{j}-\vartheta_{i}-\frac{1}{\sigma_{\varepsilon}} \frac{\gamma_{j}}{\sqrt{\sigma_{\varepsilon}^{2}+\gamma_{j}^{2}}}\left(r_{i j}-W_{i j}^{\prime} \gamma_{j} \lambda_{j}-X_{i}^{\prime}\left(\gamma_{j} \delta_{j}+\eta_{j}\right)-Z_{i}\left(\beta_{j}+\alpha_{j} \gamma_{j}\right)-\rho_{i}-\gamma_{j} \vartheta_{i}\right)}{\sqrt{1-\frac{\gamma_{j}^{2}}{\sigma_{\varepsilon}^{2}+\gamma_{j}^{2}}}}\right) \\
& -\Phi\left(\frac{\mathrm{c}_{k-1}-X_{i}^{\prime} \delta_{j}-Z_{i} \alpha_{j}-W_{i j}^{\prime} \lambda_{j}-\vartheta_{i}-\frac{1}{\sigma_{\varepsilon}} \frac{\gamma_{\mathrm{j}}}{\sqrt{\sigma_{\varepsilon}^{2}+\gamma_{\mathrm{j}}^{2}}}\left(r_{i j}-W_{i j}^{\prime} \gamma_{j} \lambda_{j}-X_{i}^{\prime}\left(\gamma_{j} \delta_{j}+\eta_{j}\right)-Z_{i}\left(\beta_{j}+\alpha_{j} \gamma_{j}\right)-\rho_{i}-\gamma_{j} \vartheta_{i}\right)}{\sqrt{1-\frac{\gamma_{\mathrm{j}}^{2}}{\sigma_{\varepsilon}^{2}+\gamma_{j}^{2}}}}\right)
\end{aligned}
$$

The assumptions on the unobserved heterogeneity is that these terms are bivariate normally distributed: $\left(\begin{array}{l}\vartheta_{i} \\ \rho_{i}\end{array}\right)=N\left(\left(\begin{array}{c}0 \\ 0\end{array}\right),\left(\begin{array}{cc}\sigma_{\vartheta}^{2} & \tau \sigma_{\rho} \sigma_{\vartheta} \\ \tau \sigma_{\rho} \sigma_{\vartheta} & \sigma_{\rho}^{2}\end{array}\right)\right)$

The individual contribution to the likelihood function is:

$$
L_{i}=\int_{-\infty-\infty}^{\infty} \int_{j=1}^{5} P\left(Y_{i j}=k \mid W_{i j}, X_{i}, Z_{i}, \vartheta_{i}, \varepsilon_{i j}+\gamma_{j} u_{i j}\right) g\left(R_{i j}=r_{i j} \mid W_{i j}, X_{i}, Z_{i}, \rho_{i}, \vartheta_{i}\right) f\left(\rho_{i}, \vartheta_{i}\right) d \rho_{i} d \vartheta_{i}
$$

where the function $f\left(\rho_{i}, \vartheta_{i}\right)$ is the density function of the bivariate normal distribution:

$$
f\left(\rho_{i}, \vartheta_{i}\right)=\frac{1}{2 \pi \sigma_{\rho} \sigma_{\vartheta} \sqrt{1-\tau^{2}}} \exp \left(-\frac{1}{2}\left(\begin{array}{c}
\rho_{i} \\
\vartheta_{i}
\end{array}\right)^{\mathrm{T}}\left(\begin{array}{cc}
\sigma_{\rho}^{2} & \tau \sigma_{\rho} \sigma_{\vartheta} \\
\tau \sigma_{\rho} \sigma_{\vartheta} & \sigma_{\vartheta}^{2}
\end{array}\right)^{-1}\left(\begin{array}{l}
\rho_{i} \\
\vartheta_{i}
\end{array}\right)\right)
$$




\section{Appendix C Derivation likelihood function for demanding occupations and} the willingness to contribute to (early) retirement scheme

This appendix derives the likelihood function of the model in section 4.2. Equation (C.1) shows the probability for a given respondent $i$ answering the questions about demanding occupations and the willingness to contribute of occupation $j$ :

$$
\begin{aligned}
P\left(Y_{i j}=k, C_{i j}=\right. & l)=P\left(c_{k-1}<y_{i j}^{*} \leq c_{k}, d_{l-1}<C_{i j}^{*} \leq d_{l}\right) \\
& =P\left(y_{i j}^{*} \leq c_{k}, C_{i j}^{*} \leq d_{l}\right)-P\left(y_{i j}^{*} \leq c_{k}, C_{i j}^{*} \leq d_{l-1}\right) \\
& -P\left(y_{i j}^{*} \leq c_{k-1}, C_{i j}^{*} \leq d_{l}\right)+P\left(y_{i j}^{*} \leq c_{k-1}, C_{i j}^{*} \leq d_{l-1}\right)
\end{aligned}
$$

The probabilities are from a bivariate normal distribution:

$$
\begin{aligned}
P\left(y_{i j}^{*} \leq c_{k+x}, C_{i j}^{*} \leq d_{l+x}\right) & \\
= & \Phi_{2}\left(\mathrm{c}_{k+x}-X_{i}^{\prime} \delta_{j}-Z_{i} \alpha_{j}-W_{i j}^{\prime} \lambda_{j}\right. \\
& \left.-\vartheta_{i}, \frac{\mathrm{d}_{l+x}-W_{i j}^{\prime} \kappa_{j} \lambda_{j}-X_{i}^{\prime}\left(\kappa_{j} \delta_{j}+\mu_{j}\right)-Z_{i}\left(\eta_{j}+\kappa_{j} \alpha_{j}\right)-\phi_{i}-\kappa_{j} \vartheta_{i}}{\sqrt{1+\kappa_{j}^{2}}}, \frac{\kappa_{j}}{\sqrt{1+\kappa_{j}^{2}}}\right)
\end{aligned}
$$

where $x \in\{0,-1\}$

The individual contribution to the likelihood is:

$$
L_{i}=\int_{-\infty}^{\infty} \int_{-\infty}^{\infty} \prod_{j=1}^{5} P\left(Y_{i j}=k, C_{i j}=l \mid \phi_{i}, \vartheta_{i}, X_{i}, Z_{i}, W_{i j}\right) f\left(\phi_{i}, \vartheta_{i}\right) d \phi_{i} d \vartheta_{i}
$$

If the particular values of $k$ and $/$ are observed and zero otherwise. The function $f\left(\rho_{i}, \vartheta_{i}\right)$ is the density function of the bivariate normal distribution:

$$
f\left(\phi_{i}, \vartheta_{i}\right)=\frac{1}{2 \pi \sigma_{\phi} \sigma_{\vartheta} \sqrt{1-\tau^{2}}} \exp \left(-\frac{1}{2}\left(\begin{array}{c}
\phi_{i} \\
\vartheta_{i}
\end{array}\right)^{\mathrm{T}}\left(\begin{array}{cc}
\sigma_{\phi}^{2} & \tau \sigma_{\phi} \sigma_{\vartheta} \\
\tau \sigma_{\phi} \sigma_{\vartheta} & \sigma_{\vartheta}^{2}
\end{array}\right)^{-1}\left(\begin{array}{l}
\phi_{i} \\
\vartheta_{i}
\end{array}\right)\right)
$$




\section{Appendix D: Descriptive statistics of the background variables}

Table D.1 Descriptive statistics for the background variables in the estimated models

\begin{tabular}{|l|c|}
\hline \multicolumn{2}{|c|}{ Mean or Percentage } \\
\hline Gender & 49.13 \\
\hline Male & 50.87 \\
\hline Female & 48.30 \\
\hline Age (years) & \\
\hline Education & 7.60 \\
\hline Primary education & 24.79 \\
\hline Lower secondary education (VMBO) & 38.50 \\
\hline Upper secondary education (HAVO/VWO) and lower vocational(MBO) & 29.11 \\
\hline Upper vocational (HBO) and University (WO) & 5.10 \\
\hline Income (Nett monthly income household) & 13.05 \\
\hline 1150 Euros or less & 25.54 \\
\hline 1151 - 1800 Euros & 56.30 \\
\hline 1801 - 2600 Euros & \\
\hline 2601 Euros or more & 65.60 \\
\hline Employment status & 12.27 \\
\hline Employed at the moment & 22.12 \\
\hline Not working at the moment, but worked in the past & 21.53 \\
\hline (Early) retired & \\
\hline Region of the Netherlands & \\
\hline North & \\
\hline West & \\
\hline East & \\
\hline South & \\
\hline Geighted data. $N=1,771$ (estimation sample). Region of the Netherlands: West = Noord- and Zuid-Holland, Utrecht and Zeeland; North $=$ \\
\hline roningen, Friesland and Drenthe; East = Overijssel, Flevoland and Gelderland; South = Noord-Brabant and Limburg. \\
\hline
\end{tabular}




\section{Appendix E: All estimation results for the model linking the extent of how}

\section{demanding occupations are to the reasonable retirement age}

This appendix shows all estimation results for the model of section 4.1.

Table E.1 Estimation of model

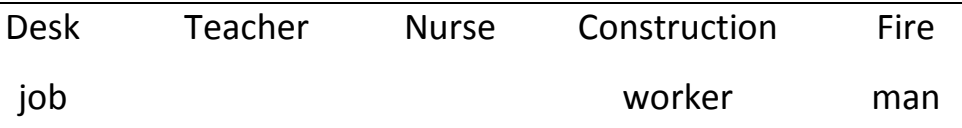

\section{How demanding}

are said

occupations?

Shifts: Quite

\begin{tabular}{|c|c|c|c|c|c|}
\hline Shifts: Quite & $\begin{array}{c}0.167^{* *} \\
(0.079)\end{array}$ & $\begin{array}{c}0.119 \\
(0.077)\end{array}$ & $\begin{array}{c}0.192 * * \\
(0.078)\end{array}$ & $\begin{array}{c}0.025 \\
(0.087)\end{array}$ & $\begin{array}{c}0.235^{* * *} \\
(0.078)\end{array}$ \\
\hline \multirow[t]{2}{*}{ Shifts: Certainly yes } & 0.051 & $0.164^{*}$ & $0.373 * * *$ & 0.042 & $0.326 * * *$ \\
\hline & $(0.100)$ & $(0.096)$ & (0.099) & $(0.113)$ & (0.099) \\
\hline \multirow[t]{2}{*}{ Physical: Quite } & $-0.662 * * *$ & -0.194 & 0.196 & $0.986^{* * *}$ & $0.602 * * *$ \\
\hline & $(0.133)$ & $(0.130)$ & $(0.131)$ & $(0.134)$ & $(0.131)$ \\
\hline \multirow[t]{2}{*}{ Physical: Certainly yes } & $-0.927 * * *$ & -0.189 & $0.504^{* * *}$ & $2.195^{* * *}$ & $1.067^{* * *}$ \\
\hline & $(0.136)$ & $(0.132)$ & $(0.134)$ & $(0.143)$ & $(0.134)$ \\
\hline \multirow[t]{2}{*}{ Time Pressure: Quite } & $0.383 * * *$ & $0.268 * * *$ & -0.001 & $-0.217^{* * *}$ & $-0.185^{* *}$ \\
\hline & $(0.075)$ & $(0.072)$ & $(0.074)$ & $(0.084)$ & $(0.074)$ \\
\hline \multirow[t]{2}{*}{ Time Pressure: Certainly yes } & $0.475^{* * *}$ & $0.486 * * *$ & $0.275^{* *}$ & $-0.335^{* *}$ & $-0.300 * *$ \\
\hline & $(0.117)$ & $(0.113)$ & $(0.118)$ & $(0.135)$ & $(0.117)$ \\
\hline \multirow[t]{2}{*}{ Responsibility: Quite } & $0.285^{* * *}$ & $0.277 * * *$ & $0.247^{* * *}$ & 0.027 & 0.106 \\
\hline & $(0.074)$ & $(0.071)$ & $(0.073)$ & $(0.083)$ & $(0.073)$ \\
\hline \multirow[t]{2}{*}{ Responsibility: Certainly yes } & $0.571 * * *$ & $0.444^{* * *}$ & $0.415^{* * *}$ & 0.078 & $0.276 * *$ \\
\hline & $(0.127)$ & $(0.124)$ & $(0.130)$ & $(0.148)$ & $(0.129)$ \\
\hline \multirow[t]{2}{*}{ Irregular working hours: Quite } & -0.007 & $0.160^{* *}$ & $0.219 * * *$ & 0.084 & $0.158^{* *}$ \\
\hline & $(0.079)$ & $(0.077)$ & $(0.079)$ & $(0.088)$ & (0.079) \\
\hline \multicolumn{6}{|l|}{ Irregular working hours: Certainly } \\
\hline \multirow[t]{2}{*}{ yes } & 0.016 & 0.121 & $0.496 * * *$ & 0.074 & $0.415^{* * *}$ \\
\hline & $(0.121)$ & $(0.118)$ & $(0.122)$ & $(0.140)$ & $(0.122)$ \\
\hline \multirow[t]{2}{*}{ Long working hours: Quite } & 0.113 & 0.086 & 0.097 & 0.037 & 0.122 \\
\hline & $(0.077)$ & $(0.074)$ & $(0.076)$ & $(0.084)$ & $(0.076)$ \\
\hline \multirow[t]{2}{*}{ Long working hours: Certainly yes } & -0.152 & 0.047 & -0.070 & $0.308 * *$ & $0.305^{* * *}$ \\
\hline & $(0.111)$ & $(0.107)$ & $(0.110)$ & (0.129) & $(0.111)$ \\
\hline \multirow[t]{2}{*}{ Many worked years: Quite } & 0.025 & $0.150 * *$ & $0.248 * * *$ & $0.200 * *$ & $0.139 * *$ \\
\hline & $(0.070)$ & $(0.068)$ & $(0.070)$ & $(0.078)$ & $(0.070)$ \\
\hline Many worked years: Certainly yes & 0.003 & $0.216^{* *}$ & $0.545^{* * *}$ & $0.451^{* * *}$ & 0.109 \\
\hline
\end{tabular}




\begin{tabular}{|c|c|c|c|c|c|}
\hline \multirow{3}{*}{ Female name of vignette person } & $(0.095)$ & $(0.091)$ & $(0.096)$ & $(0.115)$ & $(0.095)$ \\
\hline & $0.127^{* *}$ & $0.126^{* *}$ & $0.214 * * *$ & - & - \\
\hline & $(0.057)$ & $(0.056)$ & $(0.058)$ & & \\
\hline \multirow[t]{2}{*}{ gender respondent } & $0.129 *$ & 0.098 & $0.131 *$ & $0.147^{*}$ & $0.303 * * *$ \\
\hline & $(0.067)$ & $(0.065)$ & $(0.067)$ & $(0.078)$ & $(0.067)$ \\
\hline \multirow[t]{2}{*}{ Age } & $0.023 *$ & $0.024^{*}$ & 0.015 & 0.009 & $-0.031 * *$ \\
\hline & $(0.013)$ & $(0.013)$ & $(0.013)$ & $(0.016)$ & $(0.013)$ \\
\hline \multirow[t]{2}{*}{ age squared } & -0.000 & -0.000 & -0.000 & -0.000 & $0.000 * *$ \\
\hline & $(0.000)$ & $(0.000)$ & $(0.000)$ & $(0.000)$ & $(0.000)$ \\
\hline \multirow[t]{2}{*}{ Family income less than 1150 Euro } & -0.013 & 0.020 & -0.040 & 0.109 & 0.117 \\
\hline & $(0.130)$ & $(0.125)$ & (0.129) & $(0.154)$ & $(0.130)$ \\
\hline \multicolumn{6}{|l|}{ Family income between 1151 and } \\
\hline \multirow[t]{2}{*}{1800 Euro } & -0.057 & 0.110 & 0.084 & 0.145 & $0.181^{*}$ \\
\hline & $(0.092)$ & $(0.089)$ & $(0.093)$ & $(0.109)$ & $(0.093)$ \\
\hline \multicolumn{6}{|l|}{ Family income between 1801 and } \\
\hline \multirow[t]{2}{*}{2600 Euro } & -0.078 & $0.134^{*}$ & 0.050 & 0.134 & $0.160^{* *}$ \\
\hline & $(0.073)$ & $(0.070)$ & $(0.073)$ & $(0.086)$ & $(0.073)$ \\
\hline \multirow[t]{2}{*}{ basisonderwijs } & $-0.304 * *$ & -0.192 & 0.072 & 0.168 & -0.040 \\
\hline & $(0.154)$ & $(0.149)$ & $(0.154)$ & $(0.180)$ & $(0.153)$ \\
\hline \multirow[t]{2}{*}{ vmbo } & -0.104 & -0.111 & $0.196 * *$ & $0.267 * * *$ & 0.070 \\
\hline & $(0.081)$ & $(0.078)$ & $(0.082)$ & $(0.096)$ & $(0.082)$ \\
\hline \multirow[t]{2}{*}{ mbo+havo/vwo } & -0.085 & -0.079 & $0.182^{* *}$ & $0.167^{*}$ & $0.162^{* *}$ \\
\hline & $(0.075)$ & $(0.073)$ & $(0.076)$ & $(0.087)$ & $(0.076)$ \\
\hline \multirow[t]{2}{*}{ Region North } & -0.065 & $-0.284^{* * *}$ & $-0.256 * * *$ & -0.091 & 0.040 \\
\hline & $(0.095)$ & $(0.092)$ & $(0.095)$ & $(0.109)$ & $(0.096)$ \\
\hline \multirow[t]{2}{*}{ Region East } & 0.123 & $-0.148^{*}$ & -0.075 & 0.019 & -0.026 \\
\hline & (0.079) & $(0.077)$ & $(0.080)$ & $(0.093)$ & $(0.080)$ \\
\hline \multirow[t]{2}{*}{ Region South } & 0.041 & $-0.185^{* *}$ & $-0.164 * *$ & -0.002 & -0.057 \\
\hline & $(0.077)$ & $(0.074)$ & $(0.077)$ & $(0.089)$ & $(0.077)$ \\
\hline \multicolumn{6}{|l|}{ Not in a job now, but worked } \\
\hline \multirow[t]{2}{*}{ before } & -0.098 & 0.021 & -0.024 & 0.136 & 0.084 \\
\hline & $(0.098)$ & $(0.095)$ & (0.099) & $(0.118)$ & (0.099) \\
\hline \multirow[t]{2}{*}{ (Early) retirement } & -0.160 & 0.023 & 0.026 & 0.131 & 0.144 \\
\hline & $(0.105)$ & $(0.102)$ & $(0.106)$ & $(0.124)$ & $(0.105)$ \\
\hline \multirow[t]{2}{*}{ Teacher (self-identification) } & $-0.215^{* *}$ & $0.426 * * *$ & $0.193 * *$ & 0.111 & 0.005 \\
\hline & $(0.089)$ & $(0.087)$ & $(0.090)$ & $(0.104)$ & $(0.090)$ \\
\hline \multirow[t]{2}{*}{ Nurse (self-identification) } & $-0.417^{* * *}$ & $-0.188^{* *}$ & 0.010 & -0.064 & -0.064 \\
\hline & $(0.082)$ & $(0.079)$ & $(0.082)$ & $(0.095)$ & $(0.082)$ \\
\hline \multirow[t]{2}{*}{ Construction Worker (self-identification) } & $-0.267^{* *}$ & $-0.283^{* * *}$ & $-0.345^{* * *}$ & 0.010 & $-0.191 *$ \\
\hline & $(0.110)$ & $(0.105)$ & $(0.108)$ & $(0.128)$ & $(0.108)$ \\
\hline
\end{tabular}


Fireman (self-identification)

Constant

\section{What is a reasonable}

retirement age

\[ \gamma_{j} \]
Female name of vignette person

$-0.552 * * *$

(0.036)

$-0.815^{* * *}$

$-0.836 * * *$

$-0.738 * * *$

$-0.960 * * *$

Female name of vignette person

gender respondent

Age

age squared

Family income less than 1150 Euro

Family income between 1151 and 1800 Euro

Family income between 1801 and

$$
2600 \text { Euro }
$$

basisonderwijs

vmbo

mbo+havo/vwo

Region North

Region East

Region South

Not in a job now, but worked

before

(Early) retirement
$-0.258 * * * \quad-0.248 * * * \quad-0.241 * * *$

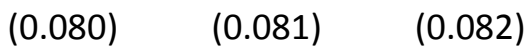

$-0.201 * \quad-0.376 * * * \quad-0.244 * *$

$\begin{array}{lll}(0.109) \quad(0.110) & \text { (0.111) }\end{array}$

$-0.339 * * *$

0.021

$-0.016$

$-0.002$

(0.114)

(0.112)

(0.021)

(0.022)

(0.022)

$0.045^{* *}$

$-0.012$

0.000

0.000

0.000

(0.022)

(0.022)

(0.000)

(0.000)

(0.000)

$-0.000$

0.000

$-0.024$

0.102

$-0.235$

(0.000)

(0.000)

(0.214)

(0.216)

(0.217)

$-0.057$

0.354

$$
0.246
$$

0.066

0.012

$-0.134$

(0.219)

(0.153)

(0.155)

(0.156)

(0.161)

(0.157)

$\begin{array}{lllll}-0.033 & 0.023 & -0.041 & -0.134 & 0.047\end{array}$

(0.120)

(0.121)

(0.123)

(0.126)

(0.123)

$-0.377$

$-0.780 * * *$

$-0.269$

0.057

$-0.443^{*}$

(0.242)

(0.244)

(0.247)

(0.254)

(0.247)

$-0.556 * * *$

$-0.784 * * *$

$-0.496 * * *$

$-0.093$

$-0.216$

(0.134)

(0.135)

(0.137)

(0.141)

(0.137)

$-0.306 *$

$-0.519 * * *$

$-0.151$

$-0.103$

$-0.325 * *$

(0.126)

(0.127)

(0.129)

(0.132)

(0.129)

$-0.206$

$-0.075$

$-0.082$

0.063

0.025

(0.160)

(0.162)

(0.163)

(0.167)

(0.164)

0.050

0.097

0.153

0.038

$0.296 * *$

(0.132)

(0.133)

(0.134)

(0.138)

(0.135)

$-0.283 * *$

$-0.141$

$-0.183$

$-0.209$

$-0.060$

(0.126)

(0.127)

(0.129)

(0.132)

(0.129)

$-0.075-0.271 *$

$-0.372 * *$

$-0.288^{*}$

$-0.250$

(0.161) (0.163)

(0.164)

(0.170)

(0.165)

$-0.047$

$-0.085$

$-0.352 *$

$-0.156$
$-0.012$ 


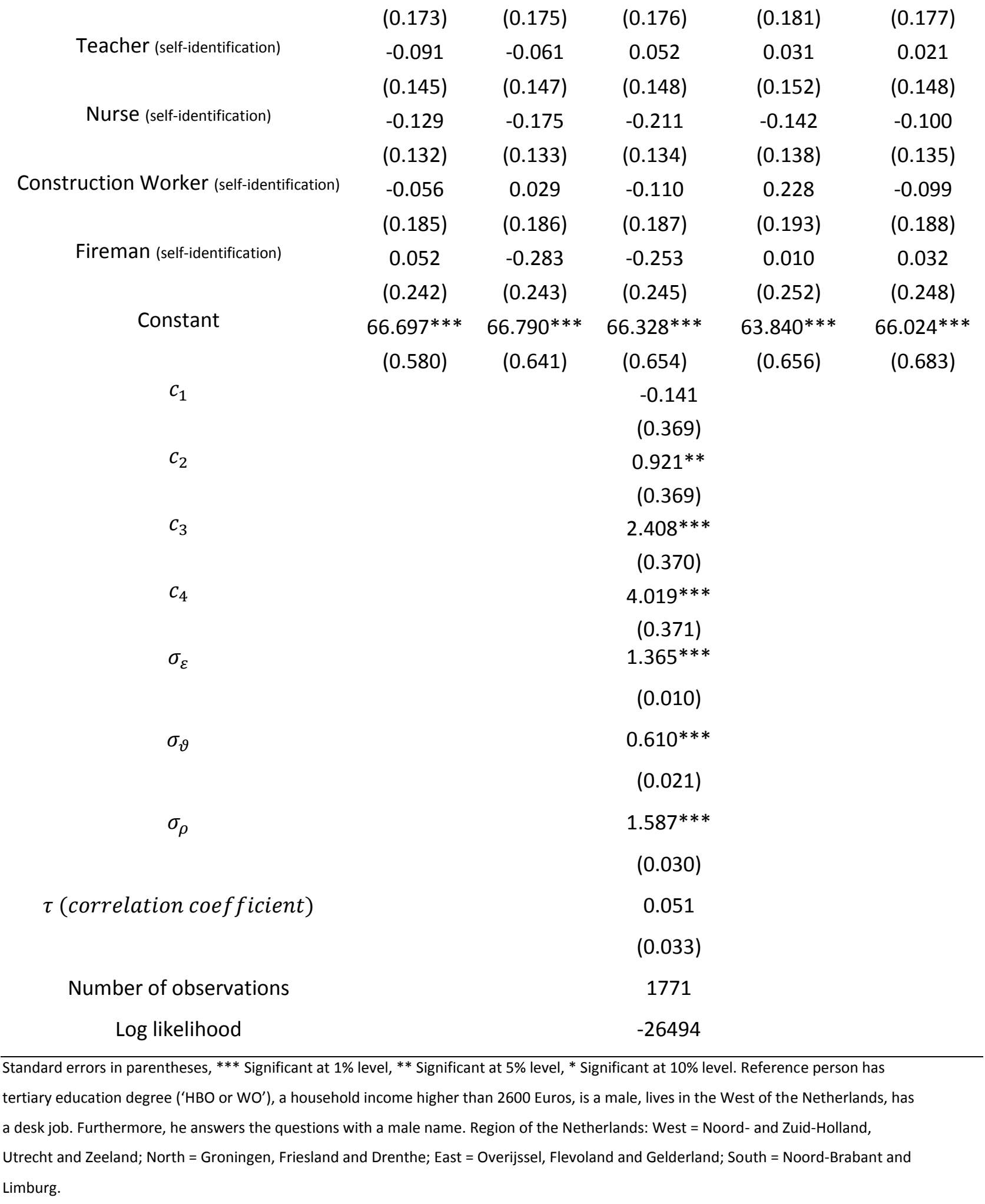




\section{Appendix F: Estimation results for the model linking the extent of how}

\section{demanding occupations are to the willingness to contribute to early}

\section{retirement schemes for certain professions}

This appendix shows the complete table with the estimation results for the model of section 4.2.

Table F.1 Estimation of model

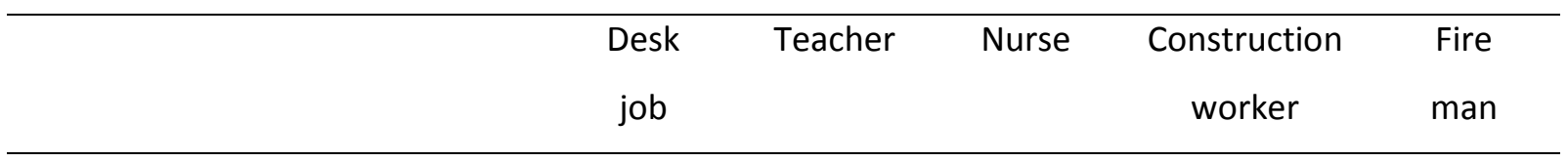

\section{How demanding}

are said

occupations?

\begin{tabular}{|c|c|c|c|c|c|}
\hline Shifts: Quite & $\begin{array}{c}0.172 * * \\
(0.075)\end{array}$ & $\begin{array}{l}0.139 * \\
(0.075)\end{array}$ & $\begin{array}{c}0.186 * * \\
(0.078)\end{array}$ & $\begin{array}{c}0.000 \\
(0.091)\end{array}$ & $\begin{array}{c}0.283^{* * *} \\
(0.079)\end{array}$ \\
\hline \multirow[t]{2}{*}{ Shifts: Certainly yes } & 0.025 & $0.163^{*}$ & $0.388 * * *$ & 0.073 & $0.352 * * *$ \\
\hline & $(0.094)$ & $(0.094)$ & $(0.100)$ & $(0.120)$ & $(0.101)$ \\
\hline \multirow[t]{2}{*}{ Physical: Quite } & $-0.629 * * *$ & $-0.256 * *$ & 0.153 & $0.957^{* * *}$ & $0.527^{* * *}$ \\
\hline & (0.129) & $(0.128)$ & $(0.132)$ & $(0.136)$ & $(0.133)$ \\
\hline \multirow[t]{2}{*}{ Physical: Certainly yes } & $-0.945 * * *$ & $-0.334 * *$ & $0.394 * * *$ & $2.192 * * *$ & $0.971 * * *$ \\
\hline & $(0.132)$ & $(0.131)$ & $(0.136)$ & $(0.145)$ & $(0.137)$ \\
\hline \multirow[t]{2}{*}{ Time Pressure: Quite } & $0.320 * * *$ & $0.244 * * *$ & -0.026 & $-0.269 * * *$ & $-0.215^{* * *}$ \\
\hline & $(0.071)$ & $(0.070)$ & $(0.074)$ & $(0.088)$ & $(0.075)$ \\
\hline \multirow[t]{2}{*}{ Time Pressure: Certainly yes } & $0.427 * * *$ & $0.454 * * *$ & $0.256^{* *}$ & $-0.503 * * *$ & $-0.401 * * *$ \\
\hline & $(0.110)$ & $(0.110)$ & (0.119) & $(0.143)$ & $(0.119)$ \\
\hline \multirow[t]{2}{*}{ Responsibility: Quite } & $0.289 * * *$ & $0.279 * * *$ & $0.256^{* * *}$ & -0.012 & $0.142^{*}$ \\
\hline & $(0.070)$ & $(0.069)$ & $(0.073)$ & $(0.087)$ & $(0.074)$ \\
\hline \multirow[t]{2}{*}{ Responsibility: Certainly yes } & $0.511 * * *$ & $0.440 * * *$ & $0.493 * * *$ & 0.193 & $0.346 * * *$ \\
\hline & $(0.121)$ & $(0.121)$ & $(0.131)$ & $(0.158)$ & $(0.132)$ \\
\hline \multirow[t]{2}{*}{ Irregular working hours: Quite } & 0.035 & $0.182 * *$ & $0.245^{* * *}$ & 0.105 & $0.153^{*}$ \\
\hline & $(0.075)$ & $(0.075)$ & $(0.078)$ & $(0.091)$ & $(0.079)$ \\
\hline \multicolumn{6}{|l|}{ Irregular working hours: } \\
\hline \multirow[t]{2}{*}{ Certainly yes } & -0.067 & 0.046 & $0.390 * * *$ & -0.058 & $0.361 * * *$ \\
\hline & $(0.115)$ & $(0.115)$ & $(0.123)$ & $(0.148)$ & $(0.124)$ \\
\hline \multirow[t]{2}{*}{ Long working hours: Quite } & $0.127^{*}$ & 0.109 & 0.108 & 0.080 & $0.160 * *$ \\
\hline & $(0.073)$ & $(0.072)$ & $(0.076)$ & $(0.087)$ & $(0.076)$ \\
\hline \multicolumn{6}{|l|}{ Long working hours: Certainly } \\
\hline \multirow[t]{2}{*}{ yes } & -0.053 & 0.099 & 0.016 & $0.483 * * *$ & $0.408^{* * *}$ \\
\hline & $(0.105)$ & $(0.103)$ & $(0.110)$ & $(0.138)$ & $(0.112)$ \\
\hline Many worked years: Quite & -0.050 & 0.064 & $0.162 * *$ & $0.141^{*}$ & 0.056 \\
\hline
\end{tabular}


Many worked years: Certainly

$$
\begin{array}{lllll}
(0.066) & (0.066) & (0.070) & (0.082) & (0.071)
\end{array}
$$$$
\text { yes }
$$

$\begin{array}{lllll}-0.092 & 0.106 & 0.443 * * * & 0.513^{* * *} & 0.058\end{array}$

Female name of vignette person

$\begin{array}{lllll}(0.089) & (0.089) & (0.096) & (0.125) & \text { (0.097) }\end{array}$

gender respondent

$0.153 * * * \quad 0.143 * * \quad 0.230 * * *$

$\begin{array}{lll}\text { (0.058) } & (0.057) \quad(0.059)\end{array}$

$\begin{array}{ccccc}0.128 * & 0.103 & 0.129 * & 0.128 & 0.302^{* * *} \\ (0.067) & (0.066) & (0.069) & (0.080) & (0.069) \\ 0.022 & 0.023^{*} & 0.015 & 0.003 & -0.037^{* * *} \\ (0.014) & (0.013) & (0.014) & (0.016) & (0.014) \\ -0.000 & -0.000 & -0.000 & 0.000 & 0.000^{* *} \\ (0.000) & (0.000) & (0.000) & (0.000) & (0.000)\end{array}$

Family income less than 1150

Euro

$\begin{array}{lllll}-0.039 & -0.003 & -0.046 & 0.123 & 0.114 \\ (0.130) & (0.128) & (0.131) & (0.158) & (0.134)\end{array}$

Family income between 1151 and 1800 Euro

$\begin{array}{lllll}-0.079 & 0.099 & 0.077 & 0.150 & 0.160 * \\ (0.093) & (0.091) & (0.095) & (0.111) & (0.095)\end{array}$

Family income between 1801 and 2600 Euro

$\begin{array}{lllll}-0.075 & 0.140^{*} & 0.068 & 0.176^{* *} & 0.153^{* *}\end{array}$

basisonderwijs

$\begin{array}{lllll}(0.073) & (0.072) & (0.075) & (0.089) & (0.075)\end{array}$

$\begin{array}{lllll}-0.241 & -0.152 & 0.114 & 0.114 & 0.014\end{array}$

$\begin{array}{lllll}(0.157) & (0.153) & (0.158) & (0.184) & (0.159)\end{array}$

vmbo

$\begin{array}{lllll}-0.067 & -0.091 & 0.217 * * * & 0.298 * * * & 0.101\end{array}$

mbo+havo/vwo

(0.082)

$(0.080) \quad(0.084)$

(0.099)

(0.084)

$\begin{array}{lllll}-0.071 & -0.085 & 0.169 * * & 0.131 & 0.156 * *\end{array}$

Region North

(0.076)

(0.075)

(0.078)

(0.089)

(0.078)

$-0.083 \quad-0.308 * * * \quad-0.276 * * *$

$-0.130$

0.033

$\begin{array}{lll}(0.096) & (0.094) \quad(0.098)\end{array}$

(0.113)

(0.099)

Region East

$0.090 \quad-0.170 * * \quad-0.093$

$-0.003$

$-0.047$

$(0.080)$

(0.079) (0.082)

(0.096)

(0.082)

Region South

$0.022-0.204 * * * \quad-0.179 * *$

$-0.025$

$-0.076$

$(0.077)$

(0.076)

(0.079)

(0.092)

(0.079)

Not in a job now, but worked

$\begin{array}{ccccc}-0.104 & 0.030 & -0.032 & 0.205^{*} & 0.088 \\ (0.099) & (0.098) & (0.102) & (0.122) & (0.102) \\ -0.144 & 0.028 & 0.017 & 0.141 & 0.133 \\ (0.106) & (0.105) & (0.109) & (0.128) & (0.108) \\ -0.189 * * & 0.454 * * * & 0.218 * * & 0.121 & 0.028 \\ (0.089) & (0.088) & (0.092) & (0.106) & (0.092)\end{array}$


$\begin{array}{cccccc}\text { Nurse (self-identification) } & -0.373^{* * *} & -0.152^{*} & 0.053 & -0.025 & -0.041 \\ & (0.082) & (0.080) & (0.084) & (0.098) & (0.084)\end{array}$

Construction Worker (selfidentification)

Fireman (self-identification)

$\begin{array}{ccccc}-0.257^{* *} & -0.248 * * & -0.327^{* * *} & 0.048 & -0.164 \\ (0.110) & (0.107) & (0.110) & (0.132) & (0.111)\end{array}$

Constant (self-identification)

$-0.163$

$-0.056$

$-0.163$

0.089

$0.390 * * *$

(0.143)

(0.139)

(0.143)

(0.169)

(0.149)

$0.5791 .496 * * *$

2.276***

$2.768 * * *$

(0.461)

(0.470)

(0.516)

(0.476)

\section{Willingness to}

contribute

\begin{tabular}{cccccc}
\multicolumn{1}{c}{$\kappa_{j}$} & $1.492^{* * *}$ & $1.294^{* * *}$ & $0.766^{* * *}$ & $0.564^{* * *}$ & $0.654^{* * *}$ \\
& $(0.073)$ & $(0.060)$ & $(0.042)$ & $(0.037)$ & $(0.035)$ \\
Female name of vignette person & -0.123 & -0.014 & 0.126 & - & - \\
& $(0.093)$ & $(0.086)$ & $(0.078)$ & & \\
gender respondent & -0.194 & -0.152 & 0.098 & 0.108 & 0.022 \\
& $(0.141)$ & $(0.137)$ & $(0.138)$ & $(0.142)$ & $(0.139)$ \\
age & $-0.071^{* *}$ & $-0.061^{* *}$ & -0.016 & -0.016 & -0.026 \\
& $(0.030)$ & $(0.029)$ & $(0.030)$ & $(0.030)$ & $(0.030)$ \\
age squared & $0.001^{* *}$ & $0.001^{* *}$ & 0.000 & 0.000 & 0.000 \\
& $(0.000)$ & $(0.000)$ & $(0.000)$ & $(0.000)$ & $(0.000)$
\end{tabular}

Family income less than 1150

Euro

$\begin{array}{lllll}0.347 & 0.452^{*} & 0.244 & 0.250 & 0.179\end{array}$

$\begin{array}{lllll}(0.263) & (0.253) \quad(0.251) & (0.258)\end{array}$

Family income between 1151 and 1800 Euro

$\begin{array}{lllll}0.246 & 0.156 & 0.118 & 0.000 & 0.205\end{array}$

Family income between 1801

$\begin{array}{llll}(0.198) & (0.192) \quad(0.192) \quad(0.197) \quad(0.193)\end{array}$

$\begin{array}{cccccc}\text { and 2600 Euro } & 0.195 & -0.050 & 0.141 & 0.227 & 0.234 \\ \text { basisonderwijs } & (0.155) & (0.152) & (0.151) & (0.155) & (0.152) \\ & 0.537^{*} & 0.117 & -0.178 & -0.257 & -0.293 \\ \text { vmbo } & (0.320) & (0.310) & (0.312) & (0.322) & (0.317) \\ & 0.314^{*} & -0.157 & -0.286 & -0.378^{* *} & -0.176 \\ \text { mbo+havo/vwo } & (0.178) & (0.174) & (0.176) & (0.181) & (0.176) \\ & 0.130 & -0.031 & -0.210 & -0.170 & -0.108 \\ \text { Region North } & (0.163) & (0.158) & (0.159) & (0.163) & (0.160) \\ & 0.484 * & 0.298 & 0.337^{*} & 0.346 * & 0.151 \\ \text { Region East } & (0.205) & (0.200) & (0.203) & (0.208) & (0.204) \\ & 0.141 & 0.207 & 0.143 & 0.147 & -0.017 \\ & (0.178) & (0.174) & (0.174) & (0.179) & (0.175)\end{array}$




\begin{tabular}{|c|c|c|c|c|c|}
\hline Region South & $\begin{array}{c}0.048 \\
(0.163)\end{array}$ & $\begin{array}{c}-0.065 \\
(0.158)\end{array}$ & $\begin{array}{r}-0.113 \\
(0.157)\end{array}$ & $\begin{array}{l}-0.058 \\
(0.160)\end{array}$ & $\begin{array}{l}-0.206 \\
(0.158)\end{array}$ \\
\hline \multicolumn{6}{|l|}{ Not in a job now, but worked } \\
\hline \multirow[t]{2}{*}{ before } & $0.614^{* * *}$ & 0.300 & 0.326 & 0.147 & 0.256 \\
\hline & $(0.209)$ & $(0.203)$ & $(0.203)$ & $(0.209)$ & $(0.204)$ \\
\hline \multirow[t]{2}{*}{ (Early) retirement } & -0.076 & -0.117 & 0.063 & 0.233 & 0.286 \\
\hline & $(0.219)$ & $(0.215)$ & $(0.217)$ & $(0.223)$ & $(0.218)$ \\
\hline \multirow[t]{2}{*}{ Teacher (self-identification) } & 0.149 & -0.061 & -0.021 & -0.059 & -0.032 \\
\hline & $(0.189)$ & $(0.185)$ & (0.184) & (0.189) & $(0.185)$ \\
\hline \multirow[t]{2}{*}{ Nurse (self-identification) } & $0.716^{* * *}$ & $0.333^{* *}$ & $0.375^{* *}$ & $0.421^{* *}$ & $0.370^{* *}$ \\
\hline & $(0.175)$ & $(0.168)$ & $(0.168)$ & $(0.173)$ & $(0.170)$ \\
\hline \multirow[t]{2}{*}{$\begin{array}{l}\text { Construction Worker (self- } \\
\text { identification) }\end{array}$} & 0.381 & 0.364 & $0.545^{* *}$ & $0.656 * * *$ & $0.590 * *$ \\
\hline & $(0.239)$ & $(0.232)$ & $(0.231)$ & $(0.237)$ & $(0.232)$ \\
\hline \multirow[t]{2}{*}{ Fireman (self-identification) } & $0.552^{*}$ & 0.235 & 0.463 & 0.198 & 0.468 \\
\hline & $(0.302)$ & $(0.293)$ & $(0.290)$ & $(0.297)$ & $(0.293)$ \\
\hline \multirow[t]{2}{*}{ Constant } & - & -0.749 & -0.966 & -0.304 & -0.003 \\
\hline & & $(0.578)$ & $(0.606)$ & $(0.653)$ & $(0.630)$ \\
\hline \multirow[t]{2}{*}{$c_{1}$} & & & -0.137 & & \\
\hline & & & $(0.372)$ & & \\
\hline \multirow[t]{2}{*}{$c_{2}$} & & & $0.861 * *$ & & \\
\hline & & & $(0.373)$ & & \\
\hline \multirow[t]{2}{*}{$c_{3}$} & & & $2.316^{* * *}$ & & \\
\hline & & & $(0.374)$ & & \\
\hline \multirow[t]{2}{*}{$c_{4}$} & & & $3.945^{* * *}$ & & \\
\hline & & & $(0.375)$ & & \\
\hline \multirow[t]{2}{*}{$d_{1}$} & & & -1.441 & & \\
\hline & & & $(0.926)$ & & \\
\hline \multirow[t]{2}{*}{$d_{2}$} & & & 0.752 & & \\
\hline & & & $(0.924)$ & & \\
\hline \multirow[t]{2}{*}{$d_{3}$} & & & $2.635^{* * *}$ & & \\
\hline & & & $(0.923)$ & & \\
\hline \multirow[t]{2}{*}{$d_{4}$} & & & $5.378 * * *$ & & \\
\hline & & & $(0.925)$ & & \\
\hline \multirow[t]{2}{*}{$\sigma_{\vartheta}$} & & & $0.606 * * *$ & & \\
\hline & & & $(0.018)$ & & \\
\hline \multirow[t]{2}{*}{$\sigma_{\phi}$} & & & $2.731^{* * *}$ & & \\
\hline & & & $(0.077)$ & & \\
\hline \multirow[t]{2}{*}{$\tau$ (correlation coefficient) } & & & $0.516^{* * *}$ & & \\
\hline & & & $(0.021)$ & & \\
\hline
\end{tabular}


number of observations

Log likelihood
1771

$-18096$

Standard errors in parentheses; ${ }^{* * *}$ Significant at $1 \%$ level, ${ }^{* *}$ Significant at $5 \%$ level, ${ }^{*}$ Significant at $10 \%$ level. Reference person has tertiary education degree ('HBO or WO'), a household income higher than 2600 Euros, is a male, lives in the West of the Netherlands, has a desk job. Furthermore, he answers the questions with a male name. Region of the Netherlands: West = Noord- and Zuid-Holland,

Utrecht and Zeeland; North = Groningen, Friesland and Drenthe; East = Overijssel, Flevoland and Gelderland; South = Noord-Brabant and Limburg. 


\section{Appendix G: Estimation with stance towards statutory retirement age}

\section{increase}

This appendix shows the distribution of the stance towards the statutory retirement age over the respondents. It also shows re-estimation of the model with this answers to this question included as additional variables. For the stance on the statutory retirement age increase the distribution of the answers for the following question is examined:

To make sure that the general old-age pension remains affordable certain measures have to be taken.

Which of the following measures appeals to you most?

1 A lower general old-age pension.

2 An increase of the old-age pension premium for people working.

3 Increase the age by two years on which I will receive the general old-age pension.

Figure G.1 shows the distribution of the answers over the respondents.

Figure G.1

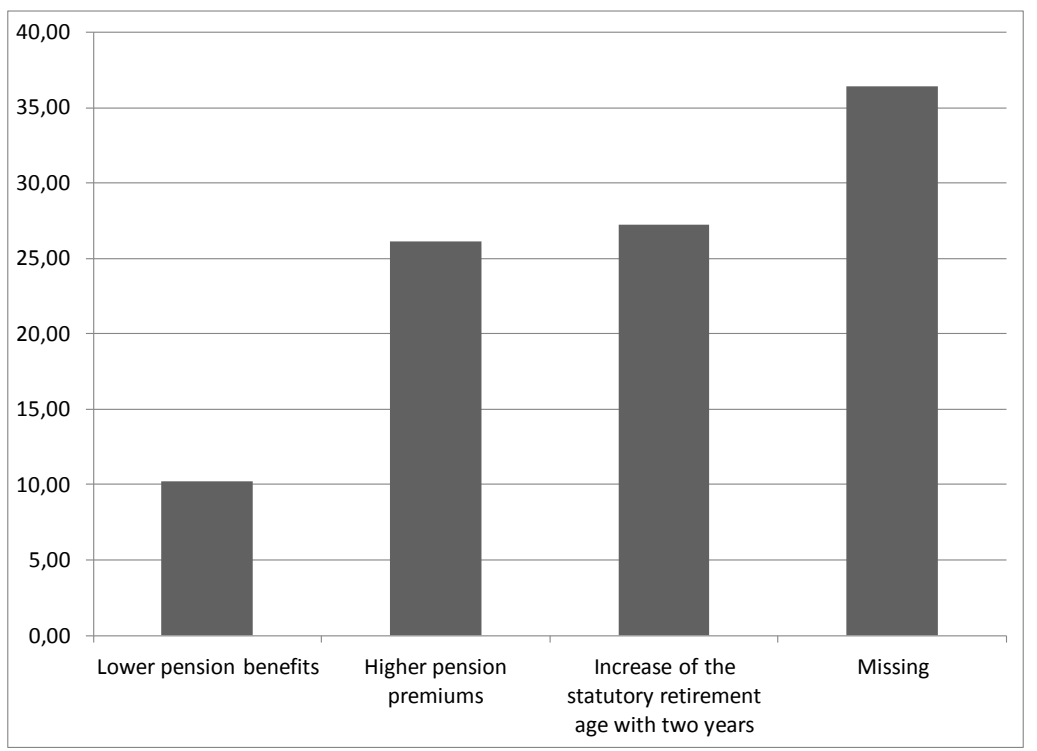

Legend: answer to the question: " To make sure that the general old-age pension remains affordable certain measures have to be taken. Which of the following measures appeals to you most?" $\mathrm{N}=1,771$. Source: DHS, own computations

Note that the question was asked only to respondents younger than 65 years of age. This implies that a large part (68\%) of the 'missing' category consists of respondents at least this age. 
Table G.1 Estimation of model for reasonable retirement age including opinion about AOW reform

\begin{tabular}{|c|c|c|c|c|c|}
\hline & $\begin{array}{l}\text { Desk } \\
\text { job }\end{array}$ & Teacher & Nurse & $\begin{array}{c}\text { Construction } \\
\text { worker }\end{array}$ & $\begin{array}{l}\text { Fire } \\
\text { man }\end{array}$ \\
\hline \multicolumn{6}{|l|}{ How demanding is occupation ... } \\
\hline Shifts: Quite & $\begin{array}{c}0.163 * * \\
(0.079)\end{array}$ & $\begin{array}{c}0.115 \\
(0.077)\end{array}$ & $\begin{array}{c}0.187^{* *} \\
(0.078)\end{array}$ & $\begin{array}{c}0.187 * * \\
(0.078)\end{array}$ & $\begin{array}{c}0.231 * * * \\
(0.078)\end{array}$ \\
\hline Shifts: Certainly yes & $\begin{array}{c}0.050 \\
(0.100)\end{array}$ & $\begin{array}{l}0.162 * \\
(0.096)\end{array}$ & $\begin{array}{c}0.370^{* * *} \\
(0.099)\end{array}$ & $\begin{array}{c}0.370 * * * \\
(0.099)\end{array}$ & $\begin{array}{c}0.324^{* * *} \\
(0.099)\end{array}$ \\
\hline Physical: Quite & $\begin{array}{c}-0.653 * * * \\
(0.133)\end{array}$ & $\begin{array}{l}-0.186 \\
(0.130)\end{array}$ & $\begin{array}{c}0.202 \\
(0.132)\end{array}$ & $\begin{array}{c}0.202 \\
(0.132)\end{array}$ & $\begin{array}{c}0.607^{* * *} \\
(0.131)\end{array}$ \\
\hline Physical: Certainly yes & $\begin{array}{c}-0.923 * * * \\
(0.136)\end{array}$ & $\begin{array}{l}-0.185 \\
(0.132)\end{array}$ & $\begin{array}{c}0.507^{* * *} \\
(0.134)\end{array}$ & $\begin{array}{c}0.507^{* * *} \\
(0.134)\end{array}$ & $\begin{array}{c}1.069 * * * \\
(0.134)\end{array}$ \\
\hline Time Pressure: Quite & $\begin{array}{c}0.379 * * * \\
(0.075)\end{array}$ & $\begin{array}{c}0.265^{* * *} \\
(0.072)\end{array}$ & $\begin{array}{l}-0.003 \\
(0.074)\end{array}$ & $\begin{array}{l}-0.003 \\
(0.074)\end{array}$ & $\begin{array}{c}-0.187^{* *} \\
(0.074)\end{array}$ \\
\hline Time Pressure: Certainly yes & $\begin{array}{c}0.469 * * * \\
(0.117)\end{array}$ & $\begin{array}{c}0.480 * * * \\
(0.113)\end{array}$ & $\begin{array}{c}0.270 * * \\
(0.119)\end{array}$ & $\begin{array}{c}0.270 * * \\
(0.119)\end{array}$ & $\begin{array}{c}-0.305^{* * *} \\
(0.117)\end{array}$ \\
\hline Responsibility: Quite & $\begin{array}{c}0.285^{* * *} \\
(0.074)\end{array}$ & $\begin{array}{c}0.276^{* * *} \\
(0.071)\end{array}$ & $\begin{array}{c}0.246 * * * \\
(0.073)\end{array}$ & $\begin{array}{c}0.246 * * * \\
(0.073)\end{array}$ & $\begin{array}{c}0.105 \\
(0.073)\end{array}$ \\
\hline Responsibility: Certainly yes & $\begin{array}{c}0.576^{* * *} \\
(0.127)\end{array}$ & $\begin{array}{c}0.448^{* * *} \\
(0.124)\end{array}$ & $\begin{array}{c}0.418^{* * *} \\
(0.130)\end{array}$ & $\begin{array}{c}0.418 * * * \\
(0.130)\end{array}$ & $\begin{array}{c}0.279 * * \\
(0.129)\end{array}$ \\
\hline Irregular working hours: Quite & $\begin{array}{l}-0.008 \\
(0.079)\end{array}$ & $\begin{array}{l}0.161^{* *} \\
(0.077)\end{array}$ & $\begin{array}{c}0.219 * * * \\
(0.078)\end{array}$ & $\begin{array}{c}0.219 * * * \\
(0.078)\end{array}$ & $\begin{array}{c}0.158^{* *} \\
(0.079)\end{array}$ \\
\hline $\begin{array}{l}\text { Irregular working hours: Certainly } \\
\text { yes }\end{array}$ & 0.014 & 0.118 & $0.494^{* * *}$ & $0.494^{* * *}$ & $0.413^{* * *}$ \\
\hline & (0.121) & $(0.118)$ & $(0.122)$ & $(0.122)$ & $(0.122)$ \\
\hline Long working hours: Quite & $\begin{array}{c}0.111 \\
(0.077)\end{array}$ & $\begin{array}{c}0.083 \\
(0.074)\end{array}$ & $\begin{array}{l}0.095 \\
(0.076)\end{array}$ & $\begin{array}{c}0.095 \\
(0.076)\end{array}$ & $\begin{array}{c}0.120 \\
(0.076)\end{array}$ \\
\hline Long working hours: Certainly yes & $\begin{array}{l}-0.148 \\
(0.111)\end{array}$ & $\begin{array}{c}0.052 \\
(0.107)\end{array}$ & $\begin{array}{l}-0.065 \\
(0.110)\end{array}$ & $\begin{array}{l}-0.065 \\
(0.110)\end{array}$ & $\begin{array}{c}0.310^{* * *} \\
(0.111)\end{array}$ \\
\hline Many worked years: Quite & $\begin{array}{c}0.027 \\
(0.070)\end{array}$ & $\begin{array}{l}0.152^{* *} \\
(0.068)\end{array}$ & $\begin{array}{c}0.250 * * * \\
(0.069)\end{array}$ & $\begin{array}{c}0.250 * * * \\
(0.069)\end{array}$ & $\begin{array}{l}0.143 * * \\
(0.070)\end{array}$ \\
\hline Many worked years: Certainly yes & $\begin{array}{c}0.006 \\
(0.095)\end{array}$ & $\begin{array}{l}0.220 * * \\
(0.091)\end{array}$ & $\begin{array}{c}0.550 * * * \\
(0.096)\end{array}$ & $\begin{array}{c}0.550 * * * \\
(0.096)\end{array}$ & $\begin{array}{c}0.113 \\
(0.095)\end{array}$ \\
\hline Female name of vignette person & $\begin{array}{c}0.128 * * \\
(0.057)\end{array}$ & $\begin{array}{c}0.127^{* *} \\
(0.056)\end{array}$ & $\begin{array}{c}0.215^{* * *} \\
(0.058)\end{array}$ & - & - \\
\hline gender respondent & $\begin{array}{l}0.125^{*} \\
(0.067)\end{array}$ & $\begin{array}{c}0.094 \\
(0.065)\end{array}$ & $\begin{array}{l}0.127^{*} \\
(0.067)\end{array}$ & $\begin{array}{l}0.127^{*} \\
(0.067)\end{array}$ & $\begin{array}{c}0.299 * * * \\
(0.067)\end{array}$ \\
\hline Age & $\begin{array}{l}0.023^{*} \\
(0.013)\end{array}$ & $\begin{array}{l}0.024 * \\
(0.013)\end{array}$ & $\begin{array}{c}0.015 \\
(0.013)\end{array}$ & $\begin{array}{c}0.015 \\
(0.013)\end{array}$ & $\begin{array}{c}-0.031^{* *} \\
(0.013)\end{array}$ \\
\hline age squared & -0.000 & -0.000 & -0.000 & -0.000 & $0.000 * *$ \\
\hline
\end{tabular}


Family income between 1151 and

$\begin{array}{lllll}(0.000) & (0.000) & (0.000) & (0.000) & (0.000) \\ -0.004 & 0.031 & -0.029 & -0.029 & 0.128 \\ (0.130) & (0.126) & (0.129) & (0.129) & (0.131)\end{array}$

Family income between 1801 and

$$
2600 \text { Euro }
$$

$\begin{array}{lllll}-0.052 & 0.116 & 0.089 & 0.089 & 0.187^{* *} \\ (0.092) & (0.089) & (0.093) & (0.093) & (0.093)\end{array}$

Family income more than 2600

$\begin{array}{ccccc}-0.075 & 0.138^{*} & 0.054 & 0.054 & 0.164^{* *} \\ (0.073) & (0.070) & (0.073) & (0.073) & (0.073) \\ -0.298^{*} & -0.186 & 0.077 & 0.077 & -0.033 \\ (0.154) & (0.148) & (0.153) & (0.153) & (0.153) \\ -0.104 & -0.110 & 0.196^{* *} & 0.196^{* *} & 0.070 \\ (0.081) & (0.078) & (0.082) & (0.082) & (0.082) \\ -0.083 & -0.077 & 0.184^{* *} & 0.184^{* *} & 0.164^{* *} \\ (0.075) & (0.073) & (0.076) & (0.076) & (0.076) \\ -0.063 & -0.282^{* * *} & -0.253^{* * *} & -0.253^{* * *} & 0.042 \\ (0.095) & (0.092) & (0.095) & (0.095) & (0.096) \\ 0.126 & -0.144^{*} & -0.071 & -0.071 & -0.023 \\ (0.079) & (0.077) & (0.080) & (0.080) & (0.080) \\ 0.043 & -0.183^{* *} & -0.162^{* *} & -0.162 * * & -0.055 \\ (0.077) & (0.074) & (0.077) & (0.077) & (0.077)\end{array}$

Not in a job now, but worked

before
(Early) retirement
Teacher (self-identification)
Nurse (self-identification)
Construction Worker (self-identification)

$\begin{array}{lllll}-0.101 & 0.017 & -0.028 & -0.028 & 0.080\end{array}$

$\begin{array}{lllll}(0.098) & (0.096) & (0.099) & (0.099) & (0.099)\end{array}$

$\begin{array}{lllll}-0.156 & 0.027 & 0.029 & 0.029 & 0.147\end{array}$

$\begin{array}{lllll}(0.105) & (0.102) & (0.105) & (0.105) & \text { (0.105) }\end{array}$

$\begin{array}{lllll}-0.210^{* *} & 0.431^{* * *} & 0.198^{* *} & 0.198^{* *} & 0.010\end{array}$

$\begin{array}{lllll}(0.089) & (0.087) & (0.090) & (0.090) & \text { (0.090) }\end{array}$

$\begin{array}{lllll}-0.411 * * * & -0.183^{* *} & 0.015 & 0.015 & -0.059\end{array}$

$\begin{array}{lllll}(0.082 & (0.079) & (0.082) & (0.082) & \text { (0.082) }\end{array}$

$\begin{array}{lllll}-0.269 * * & -0.285 * * * & -0.347 * * * & -0.347 * * * & -0.194 *\end{array}$

Fireman (self-identification)

$\begin{array}{lllll}(0.110) & (0.105) & (0.108) & (0.108) & (0.108)\end{array}$

$\begin{array}{lllll}-0.238^{*} & -0.134 & -0.219 & -0.219 & 0.317^{* *}\end{array}$

Constant

(0.143)

(0.138)

(0.142)

(0.142)

(0.145)

$\begin{array}{cccc}0.515 & 1.512^{* * *} & 1.512^{* * *} & 2.622^{* * *} \\ (0.451) & (0.463) & (0.463) & (0.463)\end{array}$

What is a reasonable

retirement age 
Female name of vignette person

gender respondent

Age

age squared

Family income between 1151 and 1800 Euro

Family income between 1801 and 2600 Euro

Family income more than 2600

Euro

Vmbo

mbo+havo/vwo

hbo+wo

Region North

Region East

Region South

Not in a job now, but worked

before

(Early) retirement

Teacher (self-identification)

Nurse (self-identification)

Construction Worker (self-identification)
(0.037)

(0.031)

(0.032)

$(0.032)$

(0.030)

$-0.247 * * * \quad-0.241 * * * \quad-0.240 * * *$

(0.080) (0.081) (0.083)

$-0.203 * \quad-0.377 * * * \quad-0.245^{* *}$

$-0.339 * * *$

0.021

(0.109)

(0.110)

(0.111)

(0.114)

(0.112)

$-0.009$

$-0.017$

$-0.008$

0.039*

$-0.015$

(0.022)

(0.023)

(0.023)

(0.023)

(0.023)

0.000

0.000

0.000

$-0.000$

0.000

(0.000)

(0.000)

(0.000)

(0.000)

(0.000)

$\begin{array}{lllll}-0.055 & 0.077 & -0.253 & -0.074 & 0.335 \\ (0.215) & (0.217) & (0.218) & (0.226) & \end{array}$

(0.215)

(0.217)

(0.218)

(0.226)

$(0.220)$

$\begin{array}{lllll}0.216 & 0.037 & -0.012 & -0.156 & 0.118 \\ (0.152) & (0.153) & (0.155) & (0.160) & (0.156)\end{array}$

0.006

$-0.058$

$-0.150$

0.034

(0.119)

(0.120)

(0.121)

(0.125)

(0.122)

$-0.344$

$-0.751 * * *$

$-0.244$

0.077

$-0.430 *$

(0.238)

(0.241)

(0.243)

(0.251)

(0.244)

$-0.479 * * *$

$-0.714 * * *$

$-0.436 * * *$

$-0.038$

$-0.168$

(0.134)

(0.136)

(0.137)

(0.141)

(0.137)

-0.241 *

$-0.458 * * *$

$-0.097$

$-0.053$

$-0.286 * *$

(0.126)

(0.128)

(0.129)

(0.132)

(0.129)

$-0.184$

$-0.053$

$-0.059$

0.086

0.044

(0.158)

(0.160)

(0.161)

(0.165)

(0.162)

0.058

0.109

0.166

0.049

$0.305 * *$

(0.132)

(0.133)

(0.134)

(0.138)

(0.135)

$-0.255^{* *}$

$-0.113$

$-0.154$

$-0.182$

$-0.037$

(0.125)

(0.126)

(0.128)

(0.131)

(0.128)

$\begin{array}{ccccc}-0.111 & -0.296 * & -0.385 * * & -0.299 * & -0.266 \\ (0.160) & (0.162) & (0.163) & (0.169) & (0.164) \\ -0.071 & -0.362 * * & -0.066 & -0.330 * & -0.146 \\ (0.174) & (0.176) & (0.178) & (0.183) & (0.178) \\ -0.028 & -0.007 & 0.101 & 0.080 & 0.065 \\ (0.145) & (0.147) & (0.148) & (0.152) & (0.149) \\ -0.064 & -0.117 & -0.158 & -0.088 & -0.052 \\ (0.132) & (0.133) & (0.134) & (0.138) & (0.135) \\ -0.048 & 0.032 & -0.109 & 0.228 & -0.099\end{array}$




\begin{tabular}{|c|c|c|c|c|c|}
\hline \multirow{3}{*}{ Fireman (self-identification) } & $(0.183)$ & $(0.184)$ & $(0.185)$ & $(0.192)$ & $(0.186)$ \\
\hline & 0.134 & -0.216 & -0.197 & 0.065 & 0.086 \\
\hline & $(0.239)$ & $(0.241)$ & $(0.243)$ & $(0.250)$ & $(0.246)$ \\
\hline \multirow[t]{2}{*}{ Pension premium increase } & $0.350^{*}$ & 0.267 & 0.240 & 0.294 & 0.317 \\
\hline & $(0.205)$ & $(0.207)$ & $(0.208)$ & $(0.210)$ & (0.209) \\
\hline \multicolumn{6}{|l|}{ Increase of two years in the } \\
\hline \multirow[t]{2}{*}{ statutory retirement age } & $1.073 * * *$ & $0.926 * * *$ & $0.836^{* * *}$ & $0.855^{* * *}$ & $0.795 * * *$ \\
\hline & $(0.203)$ & $(0.205)$ & $(0.206)$ & $(0.207)$ & $(0.207)$ \\
\hline \multirow[t]{2}{*}{ Missing } & $0.752 * * *$ & $0.568^{* * *}$ & $0.418^{*}$ & $0.446^{* *}$ & $0.489 * *$ \\
\hline & $(0.213)$ & $(0.214)$ & $(0.216)$ & $(0.217)$ & $(0.217)$ \\
\hline \multirow[t]{2}{*}{ Constant } & $65.971 * * *$ & $66.262^{* * *}$ & $65.976 * * *$ & $63.481 * * *$ & $65.612 * * *$ \\
\hline & $(0.615)$ & $(0.674)$ & $(0.685)$ & $(0.688)$ & $(0.714)$ \\
\hline \multirow[t]{2}{*}{$c_{1}$} & & & -0.130 & & \\
\hline & & & $(0.369)$ & & \\
\hline \multirow[t]{2}{*}{$c_{2}$} & & & $0.932^{* *}$ & & \\
\hline & & & $(0.369)$ & & \\
\hline \multirow[t]{2}{*}{$c_{3}$} & & & $2.418 * * *$ & & \\
\hline & & & $(0.370)$ & & \\
\hline \multirow[t]{2}{*}{$c_{4}$} & & & $4.029 * * *$ & & \\
\hline & & & $(0.371)$ & & \\
\hline \multirow[t]{2}{*}{$\sigma_{\varepsilon}$} & & & $1.365^{* * *}$ & & \\
\hline & & & $(0.010)$ & & \\
\hline \multirow[t]{2}{*}{$\sigma_{\vartheta}$} & & & $0.605^{* * *}$ & & \\
\hline & & & $(0.021)$ & & \\
\hline \multirow[t]{2}{*}{$\sigma_{\rho}$} & & & $1.551^{* * *}$ & & \\
\hline & & & $(0.029)$ & & \\
\hline \multirow[t]{2}{*}{$\tau$ (correlation coefficient) } & & & 0.052 & & \\
\hline & & & $(0.035)$ & & \\
\hline Number of observations & & & 1771 & & \\
\hline Log likelihood & & & -26467 & & \\
\hline
\end{tabular}

Standard errors in parentheses, ${ }^{* * *}$ Significant at $1 \%$ level, ${ }^{* *}$ Significant at $5 \%$ level, * Significant at $10 \%$ level. Reference person has tertiary education degree ('HBO or WO'), a household income higher than 2600 Euros, is a male, lives in the West of the Netherlands, has a desk job. Furthermore, he answers the questions with a male name. Region of the Netherlands: West = Noord- and Zuid-Holland, Utrecht and Zeeland; North = Groningen, Friesland and Drenthe; East = Overijssel, Flevoland and Gelderland; South = Noord-Brabant and Limburg. 


\begin{tabular}{|c|c|c|c|c|c|}
\hline & $\begin{array}{l}\text { Desk } \\
\text { job }\end{array}$ & Teacher & Nurse & $\begin{array}{c}\text { Construction } \\
\text { worker }\end{array}$ & $\begin{array}{l}\text { Fire } \\
\text { man }\end{array}$ \\
\hline \multicolumn{6}{|l|}{ How demanding is occupation ... } \\
\hline Shifts: Quite & $\begin{array}{c}0.171^{* *} \\
(0.075)\end{array}$ & $\begin{array}{l}0.139 * \\
(0.075)\end{array}$ & $\begin{array}{l}0.185^{* *} \\
(0.078)\end{array}$ & $\begin{array}{c}0.000 \\
(0.091)\end{array}$ & $\begin{array}{c}0.283^{* * *} \\
(0.079)\end{array}$ \\
\hline Shifts: Certainly yes & $\begin{array}{c}0.025 \\
(0.095)\end{array}$ & $\begin{array}{l}0.165^{*} \\
(0.094)\end{array}$ & $\begin{array}{c}0.388^{* * *} \\
(0.100)\end{array}$ & $\begin{array}{c}0.076 \\
(0.120)\end{array}$ & $\begin{array}{c}0.353^{* * *} \\
(0.101)\end{array}$ \\
\hline Physical: Quite & $\begin{array}{c}-0.620 * * * \\
(0.129)\end{array}$ & $\begin{array}{l}-0.246 * \\
(0.128)\end{array}$ & $\begin{array}{c}0.161 \\
(0.133)\end{array}$ & $\begin{array}{c}0.964^{* * *} \\
(0.136)\end{array}$ & $\begin{array}{c}0.534 * * * \\
(0.133)\end{array}$ \\
\hline Physical: Certainly yes & $\begin{array}{c}-0.940 * * * \\
(0.132)\end{array}$ & $\begin{array}{c}-0.325^{* *} \\
(0.131)\end{array}$ & $\begin{array}{c}0.401 * * * \\
(0.136)\end{array}$ & $\begin{array}{c}2.196 * * * \\
(0.145)\end{array}$ & $\begin{array}{c}0.977^{* * *} \\
(0.137)\end{array}$ \\
\hline Time Pressure: Quite & $\begin{array}{c}0.317^{* * *} \\
(0.071)\end{array}$ & $\begin{array}{c}0.241^{* * *} \\
(0.070)\end{array}$ & $\begin{array}{l}-0.029 \\
(0.074)\end{array}$ & $\begin{array}{c}-0.271 * * * \\
(0.088)\end{array}$ & $\begin{array}{c}-0.217^{* * *} \\
(0.075)\end{array}$ \\
\hline Time Pressure: Certainly yes & $\begin{array}{c}0.423^{* * *} \\
(0.111)\end{array}$ & $\begin{array}{c}0.452^{* * *} \\
(0.110)\end{array}$ & $\begin{array}{l}0.254^{* *} \\
(0.119)\end{array}$ & $\begin{array}{c}-0.502^{* * *} \\
(0.143)\end{array}$ & $\begin{array}{c}-0.403^{* * *} \\
(0.120)\end{array}$ \\
\hline Responsibility: Quite & $\begin{array}{c}0.291^{* * *} \\
(0.070)\end{array}$ & $\begin{array}{c}0.280 * * * \\
(0.069)\end{array}$ & $\begin{array}{c}0.256^{* * *} \\
(0.073)\end{array}$ & $\begin{array}{l}-0.013 \\
(0.087)\end{array}$ & $\begin{array}{l}0.141 * \\
(0.074)\end{array}$ \\
\hline Responsibility: Certainly yes & $\begin{array}{c}0.513^{* * *} \\
(0.121)\end{array}$ & $\begin{array}{c}0.440 * * * \\
(0.121)\end{array}$ & $\begin{array}{c}0.494 * * * \\
(0.131)\end{array}$ & $\begin{array}{c}0.196 \\
(0.158)\end{array}$ & $\begin{array}{c}0.347^{* * *} \\
(0.132)\end{array}$ \\
\hline Irregular working hours: Quite & $\begin{array}{c}0.032 \\
(0.075)\end{array}$ & $\begin{array}{c}0.180 * * \\
(0.075)\end{array}$ & $\begin{array}{c}0.243^{* * *} \\
(0.079)\end{array}$ & $\begin{array}{c}0.102 \\
(0.091)\end{array}$ & $\begin{array}{l}0.150 * \\
(0.079)\end{array}$ \\
\hline $\begin{array}{l}\text { Irregular working hours: } \\
\text { Certainly yes }\end{array}$ & -0.067 & 0.046 & $0.390 * * *$ & -0.057 & $0.362^{* * *}$ \\
\hline & $(0.115)$ & $(0.115)$ & $(0.123)$ & (0.148) & $(0.124)$ \\
\hline Long working hours: Quite & $\begin{array}{l}0.124 * \\
(0.073)\end{array}$ & $\begin{array}{c}0.105 \\
(0.072)\end{array}$ & $\begin{array}{c}0.106 \\
(0.076)\end{array}$ & $\begin{array}{c}0.078 \\
(0.087)\end{array}$ & $\begin{array}{l}0.158^{* *} \\
(0.076)\end{array}$ \\
\hline $\begin{array}{c}\text { Long working hours: Certainly } \\
\text { yes }\end{array}$ & -0.057 & 0.093 & 0.012 & $0.478 * * *$ & $0.405^{* * *}$ \\
\hline & $(0.105)$ & $(0.104)$ & $(0.111)$ & $(0.138)$ & $(0.112)$ \\
\hline Many worked years: Quite & $\begin{array}{l}-0.054 \\
(0.066)\end{array}$ & $\begin{array}{c}0.061 \\
(0.066)\end{array}$ & $\begin{array}{l}0.159 * * \\
(0.070)\end{array}$ & $\begin{array}{l}0.139 * \\
(0.082)\end{array}$ & $\begin{array}{c}0.054 \\
(0.071)\end{array}$ \\
\hline $\begin{array}{c}\text { Many worked years: Certainly } \\
\text { yes }\end{array}$ & -0.096 & 0.101 & $0.440 * * *$ & $0.511^{* * *}$ & 0.056 \\
\hline & $(0.090)$ & (0.089) & (0.096) & $(0.125)$ & $(0.097)$ \\
\hline Female name of vignette person & $\begin{array}{c}0.153^{* * *} \\
(0.058)\end{array}$ & $\begin{array}{l}0.143^{* *} \\
(0.057)\end{array}$ & $\begin{array}{c}0.229 * * * \\
(0.059)\end{array}$ & - & - \\
\hline gender respondent & $\begin{array}{l}0.129 * \\
(0.067)\end{array}$ & $\begin{array}{c}0.104 \\
(0.066)\end{array}$ & $\begin{array}{l}0.130^{*} \\
(0.069)\end{array}$ & $\begin{array}{c}0.128 \\
(0.080)\end{array}$ & $\begin{array}{c}0.303^{* * *} \\
(0.069)\end{array}$ \\
\hline
\end{tabular}




\begin{tabular}{|c|c|c|c|c|c|}
\hline age & 0.022 & $0.023^{*}$ & 0.015 & 0.003 & $-0.037 * * *$ \\
\hline & $(0.014)$ & $(0.013)$ & $(0.014)$ & $(0.016)$ & $(0.014)$ \\
\hline age squared & -0.000 & -0.000 & -0.000 & 0.000 & $0.000 * *$ \\
\hline & $(0.000)$ & $(0.000)$ & $(0.000)$ & $(0.000)$ & $(0.000)$ \\
\hline Family income less than 115 & & & & & \\
\hline Euro & -0.040 & -0.004 & -0.048 & 0.121 & 0.112 \\
\hline & $(0.130)$ & $(0.128)$ & $(0.132)$ & $(0.158)$ & $(0.134)$ \\
\hline Family income between 115 & & & & & \\
\hline and 1800 Euro & -0.079 & 0.098 & 0.076 & 0.150 & $0.160 *$ \\
\hline & $(0.093)$ & (0.091) & $(0.095)$ & $(0.111)$ & $(0.095)$ \\
\hline mily income between 180 & & & & & \\
\hline and 2600 Euro & -0.075 & $0.140^{*}$ & 0.067 & $0.177^{* *}$ & $0.152^{* *}$ \\
\hline & $(0.073)$ & $(0.072)$ & $(0.075)$ & $(0.089)$ & $(0.075)$ \\
\hline basisonderwijs & -0.240 & -0.151 & 0.115 & 0.117 & 0.015 \\
\hline & $(0.157)$ & $(0.153)$ & $(0.158)$ & $(0.184)$ & (0.159) \\
\hline vmbo & -0.068 & -0.090 & $0.217^{* * *}$ & $0.299 * * *$ & 0.102 \\
\hline & $(0.082)$ & $(0.080)$ & $(0.084)$ & (0.099) & $(0.084)$ \\
\hline mbo+havo/vwo & -0.070 & -0.082 & $0.171^{* *}$ & 0.132 & $0.157^{* *}$ \\
\hline & $(0.076)$ & $(0.075)$ & $(0.078)$ & (0.089) & $(0.078)$ \\
\hline Region North & -0.083 & $-0.308 * * *$ & $-0.276 * * *$ & -0.130 & 0.032 \\
\hline & (0.096) & $(0.094)$ & $(0.098)$ & $(0.113)$ & (0.099) \\
\hline Region East & 0.090 & $-0.171^{* *}$ & -0.094 & -0.004 & -0.048 \\
\hline & $(0.080)$ & $(0.079)$ & $(0.082)$ & $(0.096)$ & $(0.082)$ \\
\hline Region South & 0.021 & $-0.204 * * *$ & $-0.180 * *$ & -0.026 & -0.077 \\
\hline & $(0.077)$ & (0.076) & (0.079) & (0.092) & (0.079) \\
\hline Not in a job now, but worke & & & & & \\
\hline before & -0.103 & 0.031 & -0.031 & $0.205^{*}$ & 0.089 \\
\hline & (0.099) & (0.098) & (0.101) & $(0.122)$ & $(0.102)$ \\
\hline (Early) retirement & -0.145 & 0.027 & 0.016 & 0.140 & 0.132 \\
\hline & $(0.106)$ & $(0.104)$ & $(0.108)$ & $(0.127)$ & $(0.108)$ \\
\hline Teacher (self-identification) & $-0.186 * *$ & $0.456 * * *$ & $0.221 * *$ & 0.126 & 0.031 \\
\hline & $(0.089)$ & $(0.088)$ & $(0.092)$ & $(0.106)$ & $(0.092)$ \\
\hline Nurse (self-identification) & $-0.372 * * *$ & $-0.151 *$ & 0.053 & -0.025 & -0.042 \\
\hline & $(0.082)$ & $(0.080)$ & $(0.084)$ & $(0.098)$ & (0.084) \\
\hline $\begin{array}{l}\text { Construction Worker (self- } \\
\text { identification) }\end{array}$ & $-0.258 * *$ & $-0.247 * *$ & $-0.327^{* * *}$ & 0.049 & -0.164 \\
\hline & $(0.110)$ & (0.107) & $(0.110)$ & $(0.132)$ & $(0.111)$ \\
\hline Fireman (self-identification) & -0.160 & -0.054 & -0.161 & 0.087 & $0.392 * * *$ \\
\hline & $(0.143)$ & (0.139) & $(0.143)$ & (0.169) & (0.149) \\
\hline Constant & - & 0.577 & $1.494 * * *$ & $2.275^{* * *}$ & $2.768 * * *$ \\
\hline
\end{tabular}


Willingness to contribute

$$
\begin{array}{llll}
(0.461) & (0.470) \quad(0.516)
\end{array}
$$

\begin{tabular}{cccccc}
\multirow{2}{c}{$\kappa_{j}$} & $1.480^{* * *}$ & $1.282^{* * *}$ & $0.764 * * *$ & $0.569 * * *$ & $0.659 * * *$ \\
Female name of vignette person & $(0.074)$ & $(0.061)$ & $(0.042)$ & $(0.038)$ & $(0.035)$ \\
& -0.129 & -0.017 & 0.127 & - & - \\
\multirow{3}{*}{ gender respondent } & $(0.093)$ & $(0.086)$ & $(0.078)$ & & \\
& -0.204 & -0.164 & 0.088 & 0.098 & 0.010 \\
& $(0.143)$ & $(0.139)$ & $(0.139)$ & $(0.143)$ & $(0.141)$ \\
age & $-0.071^{* *}$ & $-0.061^{* *}$ & -0.009 & -0.013 & -0.020 \\
& $(0.031)$ & $(0.030)$ & $(0.031)$ & $(0.031)$ & $(0.031)$ \\
age squared & $0.001 * *$ & $0.001 *$ & 0.000 & 0.000 & 0.000 \\
& $(0.000)$ & $(0.000)$ & $(0.000)$ & $(0.000)$ & $(0.000)$
\end{tabular}

Family income less than 1150

Euro

$\begin{array}{lllll}0.340 & 0.433 * & 0.224 & 0.238 & 0.161\end{array}$

Family income between 1151

$\begin{array}{lllll}(0.266) & (0.256) & (0.255) & (0.262)\end{array}$

and 1800 Euro

$\begin{array}{lllll}0.255 & 0.158 & 0.113 & -0.006 & 0.196\end{array}$

Family income between 1801

$\begin{array}{lllll}(0.197) & (0.192) & (0.192) & (0.198)\end{array}$

and 2600 Euro

$\begin{array}{lllll}0.203 & -0.046 & 0.141 & 0.220 & 0.228\end{array}$

basisonderwijs

$\begin{array}{lllll}(0.155) & (0.151) & (0.151) & (0.155)\end{array}$

$\begin{array}{lllll}0.539 * & 0.132 & -0.150 & -0.217 & -0.250\end{array}$

$\begin{array}{lllll}(0.319) & (0.309) & (0.311) & \text { (0.321) } & \text { (0.316) }\end{array}$

vmbo

$0.292 \quad-0.164 \quad-0.271$

$-0.353^{*}$

$-0.145$

(0.179)

(0.176)

(0.178)

(0.182)

(0.178)

mbo+havo/vwo

0.115

$-0.028$

$-0.186$

$-0.133$

$-0.068$

(0.164)

(0.160)

(0.161)

(0.164)

(0.161)

Region North

$0.477^{* *}$

0.288

$0.334^{*}$

$0.352 *$

0.156

(0.205)

(0.200)

(0.203)

(0.208)

(0.204)

Region East

0.141

0.208

0.145

0.153

$-0.009$

Region South

(0.178)

(0.175)

(0.175)

(0.180)

(0.177)

0.039

$-0.077$

$-0.115$

$-0.051$

$-0.198$

(0.163)

(0.158)

(0.157)

(0.160)

(0.158)

Not in a job now, but worked

before

$\begin{array}{lllll}0.631^{* * *} & 0.320 & 0.324 & 0.145 & 0.251\end{array}$

(Early) retirement

$\begin{array}{lllll}(0.209) & (0.203) & (0.203) & (0.209) & \text { (0.204) }\end{array}$

$\begin{array}{lllll}-0.062 & -0.110 & 0.033 & 0.215 & 0.258\end{array}$

Teacher

$\begin{array}{lll}(0.225) & (0.221) & (0.222)\end{array}$

(0.228)

(0.223)

0.134

$-0.069$

$-0.014$

$-0.043$

$-0.014$

(0.189)

(0.185)

(0.184)

(0.189)

(0.185) 


\begin{tabular}{|c|c|c|c|c|c|}
\hline Nurse & $\begin{array}{c}0.694 * * * \\
(0.175)\end{array}$ & $\begin{array}{l}0.310 * \\
(0.168)\end{array}$ & $\begin{array}{c}0.367 * * \\
(0.168)\end{array}$ & $\begin{array}{c}0.423 * * \\
(0.173)\end{array}$ & $\begin{array}{c}0.371 * * \\
(0.170)\end{array}$ \\
\hline \multirow[t]{2}{*}{ Construction Worker } & 0.369 & 0.350 & $0.541^{* *}$ & $0.648^{* * *}$ & $0.587^{* *}$ \\
\hline & $(0.240)$ & $(0.233)$ & $(0.232)$ & $(0.237)$ & $(0.233)$ \\
\hline \multirow[t]{2}{*}{ Fireman } & $0.519 *$ & 0.204 & 0.461 & 0.207 & 0.474 \\
\hline & $(0.302)$ & $(0.293)$ & $(0.290)$ & $(0.297)$ & $(0.293)$ \\
\hline \multirow[t]{2}{*}{ Pension premium increase } & -0.057 & -0.307 & -0.174 & -0.103 & -0.171 \\
\hline & $(0.245)$ & $(0.240)$ & $(0.234)$ & $(0.238)$ & $(0.235)$ \\
\hline Increase of two years in the & -0.330 & $-0.484^{* *}$ & -0.148 & 0.048 & 0.009 \\
\hline statutory retirement age & $(0.245)$ & $(0.239)$ & $(0.234)$ & $(0.238)$ & $(0.235)$ \\
\hline \multirow[t]{2}{*}{ Missing } & -0.204 & -0.388 & -0.030 & 0.026 & 0.019 \\
\hline & $(0.260)$ & $(0.254)$ & $(0.249)$ & $(0.252)$ & $(0.250)$ \\
\hline \multirow[t]{2}{*}{ Constant } & - & -0.599 & $-1.211^{*}$ & -0.592 & -0.308 \\
\hline & & $(0.617)$ & $(0.643)$ & $(0.690)$ & $(0.665)$ \\
\hline \multirow[t]{2}{*}{$c_{1}$} & & & -0.135 & & \\
\hline & & & $(0.372)$ & & \\
\hline \multirow[t]{2}{*}{$c_{2}$} & & & $0.863^{* *}$ & & \\
\hline & & & $(0.373)$ & & \\
\hline \multirow[t]{2}{*}{$c_{3}$} & & & $2.320 * * *$ & & \\
\hline & & & $(0.374)$ & & \\
\hline \multirow[t]{2}{*}{$c_{4}$} & & & $3.948 * * *$ & & \\
\hline & & & $(0.375)$ & & \\
\hline \multirow[t]{2}{*}{$d_{1}$} & & & $-1.628^{*}$ & & \\
\hline & & & $(0.957)$ & & \\
\hline \multirow[t]{2}{*}{$d_{2}$} & & & 0.566 & & \\
\hline & & & $(0.955)$ & & \\
\hline \multirow[t]{2}{*}{$d_{3}$} & & & $2.449 * *$ & & \\
\hline & & & $(0.955)$ & & \\
\hline \multirow[t]{2}{*}{$d_{4}$} & & & $5.190 * * *$ & & \\
\hline & & & $(0.956)$ & & \\
\hline \multirow[t]{2}{*}{$\sigma_{\vartheta}$} & & & $0.604^{* * *}$ & & \\
\hline & & & $(0.018)$ & & \\
\hline \multirow[t]{2}{*}{$\sigma_{\phi}$} & & & $2.724^{* * *}$ & & \\
\hline & & & $(0.077)$ & & \\
\hline \multirow[t]{2}{*}{$\tau$ (correlation coefficient) } & & & $0.515^{* * *}$ & & \\
\hline & & & $(0.021)$ & & \\
\hline number of observations & & & 1771 & & \\
\hline Log likelihood & & & -18085 & & \\
\hline
\end{tabular}

Standard errors in parentheses, ${ }^{* * *}$ Significant at $1 \%$ level, ${ }^{* *}$ Significant at $5 \%$ level, * Significant at $10 \%$ level. Reference person has tertiary education degree ('HBO or WO'), a household income higher than 2600 Euros, is a male, lives in the West of the Netherlands, has 
a desk job. Furthermore, he answers the questions with a male name. Region of the Netherlands: West = Noord- and Zuid-Holland,

Utrecht and Zeeland; North = Groningen, Friesland and Drenthe; East = Overijssel, Flevoland and Gelderland; South = Noord - Brabant and Limburg. 